Kata Kovačić ${ }^{1}$

\title{
HIDRONEFROZA - PROCENA STANJA BUBREŽNOG PARENHIMA
}

\section{UVOD}

Hidronefroza je proširenje bubrežne karlice i bubrežnih čašica zbog zastoja mokraće, koji nastaje usled mehaničkih ili dinamičkih poremećaja njene evakuacije kroz pijeloureteralni segment. ${ }^{3}$

Restrikcija urinarnog protoka, ukoliko se ne leči dovešće do progresivne atrofije i destrukcije parenhima bubrega. ${ }^{24}$

U kliničkoj praksi je cilj postaviti dijagnozu opstrukcije pre nego što dođe do oštećenja parenhima i podatak o funkcionalnom stanju bubrežnog parenhima ključni je faktor za odluku o daljem lečenju.

U dijagnostici bubrežnih oboljenja metode tzv. medicinskih snimanja imaju veoma značajno mesto. Pod medicinskim snimanjima podrazumevamo metode rendgenske dijagnostike, metode nuklearne medicine, ultrazvuka i u najnovije vreme magnetne rezonance.

Među svim ovim metodama ultrazvučna dijagnostika danas ima najširu primenu, prvenstveno zato što su pregledi ultrazvukom najmanje agresivni, najjeftiniji, najšire primenljivi, gotovo bez kontraidikacija. Ne zavise od funkcije bubrega i pored bubrega mogu da pruže informacije i o mnogim drugim susednim tkivima i organima.

Ultrazvučnim pregledom se jednostavno dijagnostikuje dilatacija sabirnog sistema i u isto vreme se vizualizuje bubrežni parenhim.

Merenjem maksimalnog dijametra bubrežne karlice na transverzalnom prese$\mathrm{ku}$, određuje se stepen hidronefroze. Ultrazvukom se takođe vizualizuje dilatacija bubrežnih čašica, veličina bubrega i ehogenost parenhima. Ultrazvuk pruža odlične anatomske detalje, bez izlaganja jonizujućem zračenju ili kontrastnim sredstvima, ali je ograničen u proceni bubrežne funkcije.

Za procenu funkcije bubrega i urinarnog trakta potrebna je komplementarna radionuklidna metoda. ${ }^{10}$

\footnotetext{
1 Rad uže specijalizacije iz ultrazvuka u kliničkoj medicini, odbranjen na Medicinskom fakultetu u Beogradu, objavljujemo u skraćenom obimu.
} 
Diferencijalna renalna funkcija, dobijena DMSA statičkom scintigrafijom, pokazuje tubulsku funkciju bubrega sa hidronefrozom i važan je parametar za praćenje pacijenata.

Cilj je određivanje dobre ili loše funkcije na početku ispitivanja i uočavanje promena u funkciji u toku praćenja.

\section{HIDRONEFROZA}

\section{1. DEFINICIJA HIDRONEFROZE}

Hidronefroza je proširenje bubrežne karlice i bubrežnih čašica zbog zastoja mokraće, koji nastaje usled mehaničkih ili dinamičkih poremećaja njene evakuacije kroz pijeloureteralni segment. ${ }^{3}$

Hidronefroza može nastati usled prepreke na bilo kom mestu kanalnog sistema bubrega. U urološkom žargonu pod hidronefrozom se smatra dilatacija pijelona i čašica, koja je nastala usled prepreke na nivou pijeloureteralnog segmenta.

Hidronefroza je sinonim za dilataciju pijelokaliksnog sistema, ali nije sinonim za opstrukciju. ${ }^{23}$

Hidronefroza i dilatacija su reči koje dobro opisuju stanje urinarnog trakta u momentu pregleda klasičnim dijagnostičkim metodama (IVU, EHO). Govore nam da postoji proširenje lumena mokraćnih kanala i da se u njima mokraća nakuplja u povećanoj količini.

Iz nalaza hidronefroze ili dilatacije ne može se zaključiti da li je povećano nakupljanje mokraće u lumenu mokraćnih kanala posledica otežanog pražnjenja ili pojačanog punjenja.

Pojačano punjenje pijelokaliksnog sistema bubrega može biti rezultat hronične poliurije (insipidni dijabetes, polidipsija) ili dodatnog patološkog ,punjenja” refluksom urina iz bešike (vezikoureteralni refluks - VUR). ${ }^{16}$

Termin urinarna opstrukcija označava hidronefrozu, koja je posledica otežanog pražnjenja urina u distalne delove urotrakta.

Opstruktivna uropatija označava prisustvo prepreke oticanju mokraće sa ili bez oštećenja bubrežnog parenhima, koja nastaje zbog strukturnih ili funkcionalnih promena lokalizovanih od karlice bubrega do uretre.

Opstruktivna nefropatija podrazumeva bilo koji poremećaj funkcije ili strukture bubrega uzrokovan opstrukcijom mokraćnih kanala. ${ }^{18}$

Za kliničku upotrebu je možda najbolje definisati opstrukciju urotrakta kao svaku restrikciju urinarnog protoka, koja će ostavljena bez lečenja dovesti do progresivne atrofije i destrukcije parenhima bubrega (Homsy i Koff 1988). ${ }^{24}$

Ova definicija u sebi podrazumeva podelu urinarne opstrukcije na dva tipa: 
1. opstrukcija koja vremenom dovodi do progresivnog oštećenja bubrega i koja se zbog toga mora hirurški lečiti i

2. opstrukcija koja u perspektivi ne dovodi do pogoršanja već postojećeg oštećenja i kod koje je hirurško lečenje nepotrebno.

Problem je u tome što moramo ili čekati da opstrukcija iskaže svoj potencijal i dalje ošteti bubreg ili pomoću testova, koji su nam na raspolaganju, predvideti buduća oštećenja bubrega i na vreme pristupiti operativnom lečenju.

Pogrešno je iz nalaza hidronefroze zaključiti da, čak i onda kada se radi o opstrukcionoj leziji urinarnog trakta, neizostavno sledi dalje pojačanje dilatacije kanalikularnog sistema bubrega i propadanje bubrežne funkcije.

Da bi se potvrdila progresija hidronefroze neophodno je praćenje brojnih parametara u koje spadaju: masa nefrona, količina formiranog urina, stepen i trajanje opstrukcije, mehaničke osobine pijelokaliksnog sistema i njegova prilagodljivost (komplijansa).

Prema tome, sveobuhvatna definicija hidronefroze bi trebalo da kvalitativno i kvantitativno odredi opstrukcionu leziju, iskaže stepen postojećeg i realnu procenu budućeg funkcionalno-morfološkog oštećenja ili mogućeg postoperativnog poboljšanja.

\section{2. PATOFIZIOLOGIJA OPSTRUKCIJE}

Promene izazvane opstrukcijom urotrakta su kompleksne, a za krajnji rezultat imaju oštećenje funkcije bubrega.

Proksimalno od mesta opstrukcije razvija se zastoj mokraće sa povećanjem intraluminalnog pritiska. Staza mokraće disponira razvoj urinarne infekcije, ubrzava i pojačava oštećenje bubrega izazvano opstrukcijom.

Pijeloureteralni segment predstavlja potencijalno opstruktivnu tačku sa ograničenim kapacitetom sprovođenja tečnosti. Ako je ovaj transportni kapacitet prevaziđen (ekscesivna diureza), pijeloureteralni segment postaje opstruktivan i bez ikakvih promena u njegovom zidu i lumenu.

Kompletna, nagla opstrukcija bubrega prekida glomerulsku filtraciju i tubulsku sekreciju - ekskreciju. Iako i u slučaju kompletne opstrukcije postoji izvesna reapsorpcija mokraće, nema uslova za razvoj progresivne dilatacije, već se razvija primarna atrofija bubrega.

Hidronefroza se razvija kao posledica disbalansa između sekrecije i reapsorpcije mokraće.

Hronična inkompletna opstrukcija sa povećanjem intraluminalnog pritiska povećava reapsorpciju mokraće putem pijelovenskog, pijelolimfatičnog i pijelointer- 
sticijalnog refluksa. Povećana reapsorpcija obezbeđuje pad intraluminalnog pritiska i tako se uspostavlja ravnoteža između ekskrecije i reapsorpcije. Održavanje približno normalnog pritiska sprečava atrofiju bubrega i onemogućava stvaranje velike hidronefroze.

Zahvaljujući ovom ekvilibrijumu hidronefrotična dilatacija može biti dugo stacionarna. Svaki poremećaj ove ravnoteže izaziva dalju dilataciju kolektornog sistema i ubrzava atrofiju i destrukciju parenhima bubrega. ${ }^{3}$

Opstrukcija izaziva morfološke i funkcionalne poremećaje proksimalno od mesta opstrukcije. Promene zahvataju proksimalni deo uretera, pijelon, kalikse, bubrežno tkivo, njegove limfne i krvne sudove. Ureter i sabirni sistem su prošireni, a mišići u prvo vreme pokazuju hipertrofiju i hiperplaziju. Oštećenje mišića i umnožavanje vezivnog tkiva kasnije dovodi do poremećaja transmisije impulsa i slabljenja peristaltike uretera.

Efekti opstrukcije na bubrežno tkivo zavise od brzine razvoja, težine i trajanja opstrukcije. Ukoliko je mesto opstrukcije bliže bubregu, utoliko su njeni nepovoljni efekti na parenhim jače izraženi. Kompletna opstrukcija predstavlja mnogo veću opasnost po funkciju bubrega u poređenju sa inkompletnom opstrukcijom.

Opstrukcija u nivou pijeloureteralnog segmenta sprečava normalno pražnjenje sabirnog sistema, izaziva stazu mokraće i povećanje intraluminalnog pritiska.

Prve promene posle opstrukcije se dešavaju na čašicama. Normalna čašica ima polumesečast, konkavan oblik. Pod dejstvom povećanog intraluminalnog pritiska papila postaje zaravnjena, a kasnije, zbog ishemije i atrofije tkiva, odgovarajuća čašica dobija konveksan izgled.

Promene u parenhimu javljaju se iz više razloga. Povećan pritisak u čašicama i pijelonu izaziva kompresionu atrofiju parenhima. Parenhim između čašica izložen je manjoj kompresiji nego parenhim neposredno iznad čašice. Atrofija parenhima je izraženija u srednjim delovima bubrega, dok se u polovima ovaj proces odvija sporije. Drugi razlog atrofije tkiva je ishemija zbog kompresije krvnih sudova. Treći razlog atrofije tkiva je prenošenje pritiska na tubule, koji se šire, a njihove ćelije trpe pritisak $i$ ishemiju.

Akutna opstrukcija uretera pri dobroj diurezi izaziva skok tubulskog pritiska i hidrostatičkog pritiska u Bowman-ovoj čauri, zbog čega je smanjen efektivni filtracioni pritisak. Paraleleno sa porastom intratubulskog pritiska smanjuje se glomerulska filtracija. Posle akutne opstrukcije menja se i krvotok bubrega. U prvoj fazi opstrukcije pojačan je bubrežni protok krvi, zbog vazodilatacije preglomerulskih sudova. U drugoj fazi pritisak u ureteru i dalje raste, a protok krvi se smanjuje, zbog povećane rezistencije u postglomerulskim sudovima. U trećoj fazi smanjuje se pritisak u ureteru i bubrežni protok krvi zbog preglomerulske vazokonstrikcije. 
Kod hronične kompletne opstrukcije, pritisak u ureteru počinje da se smanjuje unutar prvih 24 h. Pad intrapijeličnog pritiska se nastavlja u narednih 6-8 nedelja. Pritisak u proksimalnim tubulima vraća se posle $24 \mathrm{~h}$ na normalan nivo ili čak ispod njega. Glomerulska filtracija se znatno smanjuje, ali se i dalje odvija u izvesnom stepenu, zahvaljujući pijelovenskom, pijelolimfatičnom i pijleotubulskom refluksu. Bubrežni protok krvi se smanjuje, kao i kapilarni pritisak u glomerulima, zbog konstrikcije aferentne arteriole. Hronična kompletna opstrukcija uretera praćena je progresivnim oštećenjem funkcije tubula. Već u ranoj fazi opstrukcije, najviše je oštećena sposobnost koncentracije mokraće. Posle mesec dana trajanja opstrukcije trajno je oštećena sposobnost koncentracije. Kod hronične kompletne opstrukcije su oštećene sve funkcije, osim dilucije mokraće.

Kod hronične inkompletne opstrukcije uretera su takođe značajno oštećene funkcije bubrega. Oštećene su sve funkcije nefrona, sa izuzetkom dilucije mokraće. Smanjen je bubrežni protok krvi i glomerulska filtracija. Pritisak u kapilarima glomerula je znatno veći nego u neopstruisanom bubregu. Inkompletna opstrukcija bubrega lagano i postepeno dovodi do totalnog gubitka funkcije bubrega, mada svakako sporije nego kompletna opstrukcija.

Kod bilateralne opstrukcije se uočavaju promene, koje se razlikuju od onih kod unilateralne opstrukcije.

Dok su lokalni faktori kod unilateralne opstrukcije jedini odgovorni za regulaciju protoka krvi kroz bubreg, u bilateralnoj opstrukciji se pojavljuju i sistemski (npr.neuroregulacija), koji dovode do različite reakcije bubrega na unilateralnu i bilateralnu opstrukciju.

Bilateralna opstrukcija rezultira značajnijim oštećenjem bubrega.

\section{3. SIMPTOMI I ZNACI HIDRONEFROZE}

Hidronefroza nema karakterističnu kliničku sliku. Ponekad je mesecima i godinama latentna. Povremeno ispoljavanje simptoma nalazi se kod intermitentnih hidronefroza. Hidronefroza se često krije iza simptoma osnovne bolesti, koja kao komplikaciju izaziva hidronefrozu (kamen, tumor, ureterocela, spoljašnja kompresija itd.). Glavni simptomi hidronefroze su bolovi i uvećanje bubrega.

Bolovi kod hidronefroze su tupog karaktera i dugotrajni, u vidu tištanja i nelagodnosti u slabinskom predelu. Nagla opstrukcija izaziva jake bolove u vidu bubrežne kolike, koja je praćena poremećajima mokrenja (polakiurija, dizurija) i promenama u mokraći (hematurija, piurija). Kod intermitentne opstrukcije bolovi su povremeni, a mogu se pojačati posle obilnog unošenja tečnosti. Nejasni bolovi u trbuhu mogu biti praćeni gađenjem i povraćanjem.

Kod inficirane hidronefroze postoji slika rekurentne urinarne infekcije. 
Hematurija se može javiti spontano. Nekada se javi posle kontuzije abdomena, jer je hidronefrotičan bubreg vulnerabilan. Pokretanje konkremenata u opstruisanom urinarnom traktu takođe daje hematuriju.

Uvećanje bubrega nije uvek palpabilno i postoji samo kod većih hidronefroza.

Nefrolitijaza se nalazi kod oko $20 \%$ bolesnika sa opstrukcijom pijeloureteralnog segmenta (Clark i Mallek 1987). ${ }^{3}$

Hipertenzija može pratiti opstrukciju urinarnog trakta. Mehanizam se svodi na aktivaciju sistema renin - angiotenzin - aldosteron .

Simptomi i znaci bubrežne insuficijencije se sreću kod pacijenata sa obostranom, veoma izraženom opstrukcijom, koja je dovela do gubitka bubrežne funkcije.

\section{4. DIJAGNOZA HIDRONEFROZE}

Ispitivanje bubrega treba da utvrdi postojanje hidronefroze, njen uzrok i funkcionalno stanje bubrega, kao i stanje kontralateralnog bubrega.

\section{5. 1. Ultrasonografija}

Osnovni cilj i domen ultrasonografskog pregleda je utvrđivanje anatomskomorfološkog stanja urotrakta.

O funkcionalnoj sposobnosti bubrežnog parenhima, pijelokaliksnog sistema i uretera na osnovu ultrasonografskog nalaza se zaključuje posredno.

Neškodljivost ultrazvuka i jednostavnost pregleda su osnovni razlozi što je to inicijalni pregled pri ispitivanju pacijenata, kod kojih se na osnovu anamneze, kliničkog pregleda i laboratorijskih analiza posumnja na oboljenje urotrakta.

Za potpunu eksploraciju bubrega nije dovoljno videti samo bubreg već je neophodno ispitati i predeo hilusa, vaskularne strukture i gornji deo retroperitonealnog prostora.

Iako normalna veličina bubrega pokazuje znatne individualne razlike, a takođe zavisnost od pola, životnog doba i telesne konstitucije, postoji potreba da se ustanove tačne dimenzije bubrega. Za verodostojno merenje bubrega u toku ultrasonografskog pregleda, slika mora biti tako podešena da su sve strukture bubrega dobro prikazane, a naročito krajnji delovi. Oznaku za merenje treba postaviti svojim centrom na spoljni rub kapsule bubrega.

Osim toga, pri pravljenju uzdužnih i poprečnih preseka moramo biti sigurni da smo za merenje uzeli preseke sa zaista najvećim promerima. Zbog toga je korisno ponoviti merenje više puta i uzeti u obzir najveći dobijeni rezultat.

Serijama longitudinalnih i transverzalnih preseka je moguće prikazati tri elemetarne strukture bubrega: kapsulu, parenhim i bubrežni sinus. 
Kapsula je debela, pravilna i glatke unutrašnje konture hiperehogena linearna zona, koja obuhvata bubreg.

Parenhim bubrega predstavlja pojas debljine 2-3 $\mathrm{cm}$. Ispod hiperehogene kapsule bubrega nalazi se zona manje ehogenosti, homogena sa finim odjecima čiji je intenzitet manji od intenziteta parenhima jetre i koja odgovara korteksu. Medularni deo, koga formiraju piramide je manje ehogenosti od korteksa sa kojim, zahvaljujući različitim akustičkim osobinama formira kortiko-medularnu granicu.

Bubrežni sinus predstavlja centralni ehomasiv - zonu veoma intenzivnih odjeka, koju sačinjavaju strukture visoke reflektibilnosti (zahvaljujući fibroznom i masnom tkivu): male i velike čašice, bubrežna karlica, krvni i limfni sudovi, nervi, fibrozno i masno tkivo oko njih.

Širina parenhimske zone stoji u odnosu 2:1 prema širini sinusa u fiziološkim uslovima. Ovaj odnos se menja sa starenjem, što je posledica povećanja sinusnog masnog tkiva i involutivne degeneracije $\mathrm{i}$ atrofije parenhima.

Na poprečnom preseku bubreg je kružnog ili ovalnog izgleda sa hilusom usmerenim antero-medijalno.

Pijelokaliksni sistem, koji je u uslovima dobre propulzije urina praktično kolabiran, kod hidronefroze je proširenog lumena. Bistar urin, bez primesa gnoja ili krvi se na ultrasonografiji prikazuje kao anehogena površina. U sinusu se vidi jedna ili veći broj anehogenih površina, koje su zrakasto raspoređene, jasno ograničene i koje međusobno komuniciraju. Na poprečnim presecima dilatiran pijelon je približno kružnog oblika.

Proširenje sabirnog sistema može da bude :

- parcijalno - kada se radi o dilataciji dela pijelokaliksnog sistema (npr.dilatiran je samo gornji čašični sistem, dok je ostali deo centralnog ehokompleksa normalnog izgleda);

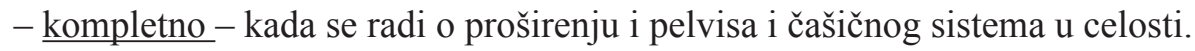

Dilatacija pijelokaliksnog sistema bubrega prema stepenu proširenosti se deli na :

- početnu - hidronefroza I stepena,

- umerenu - hidronefroza II stepena,

- izraženu - hidronefroza III stepena,

- ekstremnu - hidronefroza IV stepena. ${ }^{15}$

Hidronefroza I stepena podrazumeva početno proširenje pijelona, čiji anteroposteriorni dijametar ne prelazi $10 \mathrm{~mm}$, a parenhim bubrega je očuvan.

Hidronefroza II stepena podrazumeva proširenje pijelokaliksnog sistema od 10 do $30 \mathrm{~mm}$, takođe se očuvanim parenhimom.

Hidronefroza III stepena - kod ovog stepena dilatacija pijelokaliksnog sistema je izrazita, pa je dijametar pijelona veći od $30 \mathrm{~mm}$, a parenhim pokazuje znake 
umerene redukcije. Kod ovog stepena dilatacije sabirnog sistema bubrega dilatirana je bubrežna karlica, infundibulumi i male čašice. Operativno odstranjenje uzroka opstrukcije u ovoj fazi dovodi do zaustavljanja dalje redukcije parenhima, ali ne dovodi do njegovog oporavka.

Hidronefroza IV stepena podrazumeva ekstremnu i kompletnu dilataciju sabirnog sistema bubrega, praćenu potpunom atrofijom parenhima. $\mathrm{U}$ ovoj fazi bubreg je predstavljen cističnom formacijom većom od promera normalnog bubrega. ${ }^{15}$

U toku razvoja hidronefroze dolazi do atrofije bubrežnog parenhima. Stepen redukcije parenhima zavisi od stepena opstrukcije, od dužine njenog trajanja, od pridružene uroinfekcije ili kalkuloze. Nekada je redukcija parenhima ravnomerna, a nekada se smenjuju zone bolje ili lošije očuvanog parenhima. Kod veoma izražene hidronefroze parenhim bubrega može biti istanjen na svega par milimetara, a bubreg u celini, ispunjen urinom, liči na kesu. Afunkcionalnom bubrežnom parenhimu ehogenost korteksa raste. Što je korteks ehogeniji to je funkcionalna sposobnost parenhima slabija. Piramide medule su u hidronefrozi atrofične ili potpuno destruisane.

O stepenu oštećenja parenhima jednostrano hidronefrotičnog bubrega indirektno govori stepen kompenzatorne hipertrofije parenhima drugog bubrega. Što je kompenzatorna hipertrofija zdravog bubrega izraženija, to su kvantitet i kvalitet parenhima obolelog bubrega slabiji. ${ }^{16}$

O bubrežnoj funkciji se, dakle, ultrasonografijom može samo indirektno zaključiti da je smanjena, ako je bubrežni parenhim istanjen, jer iako su volumen i ehostruktura bubrežnog parenhima u vezi sa funkcijom bubrega, ipak nisu i njen ekvivalent.

O postojanju opstrukcije u urodinamskom smislu se na osnovu ultrasonografije ne može govoriti, jer ne postoje instrumenti, koji bi urodinamiku merili.

Za razlikovanje opstruktivnih i neopstruktivnih promena u pijelokaliksnom sistemu se može primeniti diurezna ultrasonografija i to tako što se meri dijametar pijelona pre i nakon davanja diuretika (Furosemid $0,5 \mathrm{mg} / \mathrm{kg}$ telesne težine i.v.) pacijentu, koji je prethodno dobro hidriran. Procena se bazira na relativnom porastu dijametra pijelokaliksnog sistema i vremena koje je potrebno da se sabirni sistem vrati na inicijalne dimenzije. ${ }^{27,28}$

Osim toga, u novije vreme se radi diurezna Doppler sonografija. Kod opstruisanih bubrega se već posle 10 minuta od primene Furosemida uočava značajno povećanje indeksa rezistencije, dok se kod neopstruisanih bubrega indeks rezistencije ne menja bitno. ${ }^{29}$

Vrednost ultrasonografskog pregleda povećava vremenska distanca između dva ili više pregleda, jer se tako stiče uvid u dinamiku ili stacionarnost patoloških promena. 


\section{5. 2. Intravenska urografija}

Intravenska urografija je radiografski metod kojim se anatomija urinarnog sistema prikazuje detaljno, a bubrežna funkcija se procenjuje grubo.

Metod se zasniva na ekskreciji kontrastnog sredstva preko bubrega, koje je prethodno ubrizgano intravenski.

Kontrastna sredstva, koja se koriste za intravensku urografiju (IVU) izlučuju se glomerulskom filtracijom.

Pomoću intravenske urografije funkcija bubrega se procenjuje na osnovu brzine pojave kontrasta $u$ kaliksima bubrega i brzine prikazivanja gornjeg urotrakta kontrastnim urinom.

Ovi pokazatelji variraju sa brzinom injiciranja i dozom datog kontrastnog sredstva, stanjem hidracije organizma i promenom arterijske tenzije, pa zbog toga procena funkcije bubrega nije precizna kao kod radioizotopskog metoda.

Može se zaključiti da bubreg pravovremeno izlučuje kontrastno sredstvo, t.j. da je funkcija bubrega dobra. Ako je vizualizacija pijelokaliksnog sistema bubrega odložena, bubrežna funkcija je oslabljena. Ako nema ekskrecije kontrasta, bubreg je afunkcionalan.

Na urografijama hidronefrotično izmenjenog bubrega se mogu utvrditi patološkoanatomske promene slične onima na ultrasonografiji. Volumen bubrega je povećan zbog proširenja mokraćnih kanala. Kaliksi su sfernog oblika, napeti, pijelon uvećan, zaobljene medijalne i/ili kaudalne konture, a bubrežni parenhim je istanjen.

\section{5. 3. Anterogradna pijelografija}

Anterogradna pijelografija daje sliku pijelokaliksnog sistema i proksimalnu granicu opstrukcije, ako bubreg ne luči kontrast ni na poznim snimcima infuzione urografije. Izvodi se tako što se kontrast ubrizga preko perkutane nefrostome.

\section{5. 4. Retrogradna pijelografija}

Retrogradna pijelografija se izvodi tako što se u toku cistoskopije plasira ureterski kateter kroz ureteralno ušće retrogradno do bubrežnog pijelona. Zatim se kroz ureter ubrizga kontrast u pijelokaliksni sistem bubrega.

\section{5. 5. Kompjuteriziovana tomografija}

Kompjuterizovana tomografija može da pokaže hidronefrotično uvećanje bubrega, koji ne luči kontrast na urografiji. Ova metoda je retko potrebna kod hidronefroze, ali može dobro da se proceni debljina parenhima. 


\section{5. 6. Metode nuklearne medicine}

Korišćenje neinvazivnih, osetljivih i jednostavnih nuklearno-medicinskih metoda u dijagnostici uroopstrukcije, podrazumeva dijagnostičku i istraživačku primenu radioaktivnih obeleživača za ,,in vivo" funkcionalna ispitivanja urotrakta. ${ }^{13}$

Prema tome, vizuelne informacije, koje se dobiju prikazuju urotrakt u funkcionalnom, a ne $u$ anatomskom smislu.

Uronefrološke analize u nuklearnoj medicini obuhvataju semikvantitativna i kvantitativna, dinamička i statička ispitivanja tranzita i distribucije nefrotropnih radiofarmaka. Radioindikatori se ubrizgavaju intravenski, a praćenje njihove kinetike zasnovano je na spoljnom merenju pomoću kompjuterizovane gama kamere, kao stacionarnog skening sistema.

Osnovna prednost nuklerno-medicinskog isptivanja je mogućnost procene funkcije hidronefrotično izmenjenog bubrega. Osim toga, neželjene hipersenzitivne reakcije na radiofarmake praktično ne postoje, te se mogu bezbedno koristiti i kod osoba koje pokazuju preosetljivost na jodna kontrastna sredstva. Crevni sadržaj ne ometa ispitivanje, pa nije potrebna posebna priprema. U poređenju sa radiološkim pregledima, scintigrafijom se pacijent izlaže manjim dozama jonizujućeg zračenja.

\section{5. 6. 1. Radiofarmaci:}

Osnovni principi korišćenja radiofarmaka za ispitivanje urotrakta zasnivaju se na izboru specifične supstance sa visokim nefrotropizmom i sa željenim fiziološkim putem izlučivanja, u zavisnosti od nivoa bubrežne funkcije koji se želi ispitati (glomerulska ili tubulska).

Željena svojstva radiofarmaka su: obeležavanje radionuklidom povoljnih fizičkih osobina (kratko vreme poluraspada, čista gama emisija, niska energija zračenja), visoka efikasnost ekstrakcije iz krvi, nisko vezivanje za proteine plazme zbog bolje glomerulske filtracije i tubulske sekrecije, kao i stabilnost preparata i jednostavnost upotrebe.

Najčešće korišćeni radiofarmaci su :

\section{${ }^{131} \mathrm{~J}$-ORTO-JODOHIPURAT (HIPURAN)}

Hipuran je analog para-amino-hipurne kiseline (PAH) sa sličnom biokinetikom. Izlučuje se aktivnom tubulskom sekrecijom (80\%) i glomerulskom filtracijom (20\%). Kako se već u prvom prolazu kroz bubreg iz krvi odstrani i mokraćom izluči gotovo celokupna količina radiohipurana, koja se nalazi u datoj zapremini krvi, ovaj radiofarmak je pogodan za određivanje efektivnog bubrežnog protoka plazme (ERPF). 
Nepovoljne fizičke osobine radionuklida ${ }^{131} \mathrm{~J}$ su vreme poluraspada od 8 dana, prisustvo čestičnog beta zračenja, kao i emisija gama zračenja srednje visoke energije od $364 \mathrm{keV}$-a, koja je nepovoljna za spoljna merenja gama kamerom.

Gotovo idealan obeleživač za dinamska ispitivanja gama kamerom je ${ }^{123} \mathrm{~J}-$ hipuran. ${ }^{123} \mathrm{~J}$ je ciklotronski produkt, čist gama emiter niske energije zračenja od $159 \mathrm{keV}$-a, sa kratkim vremenom poluraspada od 13,3 h. Ove izvanredne fizičke karakteristike omogućuju, uz generisanje renografskih krivih i visok kvalitet funkcionalnih slika bubrega. Za našu sredinu veoma značajan nedostatak ${ }^{123} \mathrm{~J}-\mathrm{OIH}$ je visoka cena, nepostojanje „kućnog ciklotrona” ili besprekorno organizovan brz transport. Zbog toga se više koriste radiofarmaci obeleženi ${ }^{99 \mathrm{~m}} \mathrm{Tc}-$ pertehnetatom. Generatorski proizvod tehnecijum-99m je kratkoživeći radionuklid idealnih fizičkih karakteristika sa vremenom poluraspada od $6,02 \mathrm{~h}$, čistom gama emisijom i monoenergetskim zračenjem od $140 \mathrm{keV}-\mathrm{a}$, zbog čega je izvanredno pogodan za ispitivanje na gama kameri.

\section{9mTc-DIETIL-TRIAMINO-PENTA-ACETAT (DTPA)}

Nakon intravenskog injiciranja DTPA se minimalno vezuje za proteine plazme, pa se lako filtrira kroz glomerulske kapilare. Glomerulska filtracija je jedini put njegove eliminacije iz krvi. Zbog kratkog fizičkog i biološkog poluživota, ovaj radiofarmak se koristi za ispitivanje bubrežne perfuzije u toku prvog prolaza, a zbog brze pasaže u sabirni sistem, pogodan je za dinamsku vizualizaciju bubrega uz dopunsko određivanje ukupne i separatne jačine glomerulske filtracije, kao i za izvođenje renografije.

\section{${ }^{99 m}$ Tc-DIMERKAPTOSUKCINILNA KISELINA (DMSA)}

Ovo je radiofarmak sa najboljim karakteristikama za vizualizaciju kortikalnog bubrežnog parenhima, zbog izraženog afiniteta prema ćelijama proksimalnih tubula, kao i niske urinarne ekskrecije. Vezivanje ${ }^{99 \mathrm{~m}}$ Tc-DMSA zavisi od funkcionalne kortikalne mase i renalne perfuzije. Njegova biodistribucija je zasnovana na dva mehanizma fiksacije: direktni iz peritubulskih kapilara, za šta je neophodna intaktna enzimska funkcija i indirektni kao posledica glomerulske filtracije i proksimalne tubulske reapsorpcije.

Dobre slike korteksa, bez aktivnosti u meduli i pijelokaliksnom sistemu dobijaju se 2-3 h posle i.v. injekcije. Vezivanje dostiže plato u toku $6 \mathrm{~h}$ i ostaje konstantno $24 \mathrm{~h}$.

${ }^{99 m}$ Tc-DMSA se smatra specifičnim kortikalnim obeleživačem, koji daje uvid u regionalni raspored funkcionalno sposobne mase nefrona kore bubrega, a pogodan je i za kvantitativnu procenu individualne bubrežne funkcije. 
99mTc-MERKAPTOACETIL-TRIGLICIN (MAG-3)

To je supstanca najveće biokinetičke sličnosti sa hipuranom, ali obeležena tehnecijumom. Karakteristike ${ }^{99 m}$ Tc-MAG-3 su: visoka renalna ekstrakcija, zahvaljujući kojoj se dobija izvanredan kvalitet bubrežnih dinamskih slika, dinamske krive visokog statističkog kvaliteta, mogućnost koriščenja kod izrazito redukovane bubrežne funkcije, zbog brzog plazmatskog klirensa.

${ }^{99 m}$ Tc-MAG-3 je pogodan za dinamska ispitivanja funkcije bubrega, uz mogućnost kvantitativnog određivanja brzine tubulske ekstrakcije.

\section{5. 6. 2. Nuklearno-medicinske metode koje se koriste u evaluaciji hidronefroze:}

Osnovna dijagnostička informacija nuklearno-medicinskih ispitivanja prisustva ili odsustva opstruktivne uro-nefropatije je utvrđivanje produženog tranzita radioindikatora kroz parenhim i sabirni sistem. Pritom se u slučajevima opstrukcije izazvane dilatacijom, otpor može prevazići pojačanjem protoka mokraće diureznom stimulacijom.

U prognostičkom smislu, u cilju vođenja terapije i kontrole efekata lečenja značajno je ispitivanje bubrežne funkcije na osnovu akumuliranog radiofarmaka, kao i određivanje globalnih i separatnih klirensa radioobeleženih jedinjenja.

\section{Klirens metode}

Ukupni bubrežni klirensi su osetljivi kvantitativni pokazatelji globalne bubrežne funkcije, koji se koriste za rano otkrivanje pada funkcionalne rezerve bubrega.

\section{Merenje jačine glomerulske filtracije (GFR):}

Klirens fiziološki inertne supstance, koja se efikasno i isključivo filtrira preko glomerula, a pri prolazu kroz tubule ne reapsorbuje, niti sekretuje je mera jačine glomerulske filtracije. Ove osobine zadovoljava ${ }^{99 m}$ Tc-DTPA.

\section{Određivanje efektivnog bubrežnog protoka plazme (ERPF):}

Klirens supstance koja se visokom efikasnošću ekstrakcije kompletno eliminiše iz plazme u prvom prolazu tubulskom sekrecijom, glomerulskom filtracijom ili kombinovano, je mera efektivnog bubrežnog protoka plazme. Dobijena vrednost predstavlja izračunati ,efektivni”, a ne realni volumen, jer se izuzima protok kroz medulu i intersticijalno tkivo. Radiofarmak izbora za ovu klirens studiju je ${ }^{123} \mathrm{~J}$ ili ${ }^{131} \mathrm{~J}$-hipuran. 


\section{Radiorenografija}

Radiorenografija je dinamička, semikvantitativna nuklearno-medicinska metoda, koja praćenjem kinetike radofarmaka, odražava individualnu bubrežnu funkciju i daje informaciju o transportu mokraće. Zasniva se na spoljašnjoj detekciji promena aktivnosti u funkciji vremena nad regionom bubrega, $u$ toku tranzita specifičnog i.v. ubrizganog indikatora. Generisanje kompjuterizovanih renografskih krivih vrši se u toku obrade podataka dobijenih dinamičkim studijama pomoću gama scintilacione kamere. Pritom postoji mogućnost dobijanja sekvencijalnih scintigrama, računarske subtrakcije osnovne aktivnosti i određivanja relativne separatne funkcije. Najpogodniji radofarmaci za ovo ispitivanje su ${ }^{123} \mathrm{~J} /{ }^{131} \mathrm{~J}$-hipuran, ${ }^{99 \mathrm{~m}} \mathrm{Tc}-\mathrm{DTPA}$ i ${ }^{99 \mathrm{~m}} \mathrm{Tc}-\mathrm{MAG}-3$.

Normalna renografska kriva je trosegmentnog oblika, sa oštrim vrhom i predstavlja složeni tip krive: prva faza traje 30-40 sekundi, a predstavljena je brzim i strmim usponom krive nakon aplikacije radiofarmaka. Odgovara dospevanju indikatora u vaskularni renalni i ekstrarenalni prostor. Druga faza traje od 2-5 minuta i predstavljena je takođe ushodnim, ali blažim usponom krive. Korelira sa minutnim bubrežnim protokom i bubrežnom funkcijom, a odraz je parenhimskog tranzitnog vremena radioafarmaka. Završetak ove faze je predstavljen maksimumom krive. Maksimum druge faze može biti odložen usled opstruktivnog procesa, stenoze bubrežne arterije i parenhimskog oboljenja. Kod redukovane funkcije bubrega druga faza ima blaži nagib, produžena je ili čak nedostaje. Treća faza je predstavljena eksponencijalnim padom krive posle dostignutog maksimuma. Ova faza je predominantno, ali ne i isključivo ekskretorna. Rezultat je brzine dolaska radioindikatora u bubreg, njegove eliminacije i kontinuiranog pada aktivnosti u krvi i okolnom tkivu. Opadanje aktivnosti na polovinu maksimalne vrednosti - vreme polueliminacije, nastaje obično do 8 minuta. Oblik krive $u$ trećoj fazi odražava urodinamsko ponašanje bubrega i tranzit radioindikatora kroz pijelokaliksni sistem do uretera i mokraćne bešike.

Treća faza je visoko senzitivna na poremećaje drenaže i njen normalan izgled isključuje prisustvo čak i najdiskretnijih znakova uroopstrukcije. Najraniji znak opstrukcije je zaravnjenje normalno konkavne treće faze. Elevacija trećeg segmenta je znak rastuće opstrukcije, dok je akumulaciona kriva, kod koje se zapaža izrazito produžena druga faza i odsustvo maksimuma, znak kompletne opstrukcije.

Odložena eliminacija može biti uzrokovana zadržavanjem aktivnosti u regiji bubrega nastalim zbog dehidracije, ishemije i dilatacije sabirnog sistema, što treba uvek imati u vidu.

\section{Diurezna renografija}

Diurezna renografija je modifikacija standardne renografije, koja se koristi za diferenciranje uzroka dilatacije gornjeg urotrakta. Omogućuje razlikovanje stvarne 
organske opstrukcije i hipotonije t.j. ,funkcionalne” opstrukcije u dilatiranom sabirnom sistemu.

Aplikovanjem diuretika u toku renografije, u slučajevima povećanog kapaciteta sabirnog sistema dokazuje se prisustvo ili odsustvo značajnog mehaničkog otpora toku mokraće. U oba slučaja se registruje inicijalno opstruktivna renografska kriva. Kod opstruktivne dilatacije i uprkos ubrzanoj urodinamici izazvanoj diureznom stimulacijom, eliminacioni segment krive ostaje opstruktivan. Nasuprot tome, u dilatiranom neopstruktivnom sistemu, prolongirano zadržavanje indikatora u vidnom polju detektora nastaje zbog povećanog kapaciteta kolektornog sistema i fenomena mešanja. U ovom slučaju diurezna stimulacija dovodi do prevazilaženja otpora i eliminacije radiofarmaka iz gornjeg urotrakta, što rezultuje padom eliminacionog segmenta renografkse krive.

Moguća su 4 tipa odgovora na povećanje brzine protoka mokraće:

I - normalan renogram - oba renograma su normalna, što isključuje opstrukciju;

II - odsustvo odgovora - inicijalno opstruktivna kriva ostaje opstruktivna nakon diurezne stimulacije, što ukazuje na kompletnu organsku opstrukciju;

III a - potpun odgovor - inicijalno opstruktivna kriva postaje normalna nakon diurezne stimulacije, što upućuje na dilatiran neopstruktivni sabirni sistem;

III b - nepotpun, granični, ekvivokalan odgovor - inicijalno opstruktivna kriva pokazuje parcijalni odgovor eliminacionog segmenta na diuretik, što ukazuje na subtotalnu, inkompletnu organsku opstrukciju u dilatiranom sabirnom sistemu. Ovaj odgovor je moguć i kada je bubrežna funkcija suviše redukovana da bi bilo odgovora na diureznu stimulaciju.

\section{Scintigrafija bubrega}

Scintigram bubrega je vizuelni prikaz bubrega, odnosno funkciono-topografska slika bubrežnog parenhima. Rezultat je nakupljanja nefrotropnog radioobeleživača u bubregu u skladu sa njegovim biodistribucionim osobinama.

Dinamska ili sekvencijalna scintigrafija je metoda koja u različitim vremenskim intervalima daje vizuelni prikaz pristizanja, kratkotrajnog funkcionalnog nakupljanja u parenhimu i odlaženja i.v. ubrizganog radiofarmaka sa brzom bubrežnom kinetikom. Dinamska scintigrafija je u suštini vizuelna radiorenografija. Najčešće korišćeni radiofarmaci za dinamsku scintigrafiju su ${ }^{99 \mathrm{~m} T c-D T P A},{ }^{131} \mathrm{~J}-\mathrm{OIH}$ i ${ }^{99 \mathrm{~m}} \mathrm{Tc}-\mathrm{MAG}-3$.

Statička scintigrafija (planarna) je dvodimenzionalni prikaz topografije bubrežnog funkcionalnog parenhima, u kome se radiofarmak kontinuirano nakuplja. Ovakav 
biodistribucijski put pokazuje ${ }^{99 \mathrm{~m} T c-D M S A}$, koji je referentan radiofarmak za vizuelni prikaz kortikalne funkcionalne mase. Statički scintigram daje uvid u regionalnu distribuciju funkcionalno sposobnog tkiva unutar svakog bubrega, pri čemu delovi bubrežnog parenhima koji imaju dobro očuvanu perfuziju i ekstrakcioni kapacitet tubularnih ćelija vezuju više radioobeleživača nego delovi sa lošom perfuzijom i/ili tubularnom disfunkcijom. Fotodeficijentne zone ukazuju na regionalnu afunkciju pojedinih delova parenhima.

Ova metoda omogućuje kvantitativnu procenu diferencijalne relativne funkcije, pri čemu je neophodno izvršiti korekciju na dubinu bubrega.

Kod hidronefroze rezultat statičke scintigrafije je značajan u terapijskom izboru između konzervativne hirurgije i nefrektomije.

U akutnoj opstrukciji hemodinamski pokazatelji funkcije bubrega (GFR i ERPF) ukazuju na težu disfunkciju nego DMSA statička studija, koja može biti gotovo uredna.

U hroničnoj opstruktivnoj uro-nefropatiji hemodinamski parametri su bolje očuvani od stepena očuvanosti relativne kortikalne mase, odnosno funkcionalne sposobnosti kortikalnih nefrona.

U opstrukciji visokog stepena parenhimska akumulacija kortikalnog obeleživača je izrazito oslabljena.

Primena neinvazivnih nuklearno-medicinskih metoda, komplementarnih radiološkim dijagnostičkim tehnikama omogućuje urologu procenu hidronefroze na bazi fizioloških kriterijuma.

\section{5. 7. Ispitivanje protoka i pritiska}

Za razlikovanje dilatiranog neopstruiranog od dilatiranog opstruiranog sabirnog sistema koristi se Whitaker-ov test, koji se sastoji u ispitivanju pritiska u toku perfuzije tečnosti kroz perkutanu nefrostomu.

Postavljanjem perkutane nefrostome mogu se pratiti promene nekih morfoloških i funkcionalnih osobina bubrega, koje bi se menjale na isti način kao da je opstrukcija odstranjena operativno.

\section{5. 8. Aortorenovazografija}

Angiografija može da dokaže vaskularnu opstrukciju. Na arteriografiji se može proceniti i oblast koju ishranjuju pojedine segmentne grane. Poznavanje ograničenja koja nastaju zbog određenog tipa vaskularizacije je važno za hirurga u slučaju kada se planira hirurška korekcija hidronefroze. 


\section{5. 9. Cistografija}

Pri ispitivanju bolesnika sa hidronefrozom cistografija je indikovana kada treba isključiti vezikoureteralni refluks, tada se radi i mikciona cistoureterografija (MUCG). $\mathrm{Na}$ ovaj način se prikazuje i anatomija donjeg urinarnog trakta.

\section{5. 10. Magnetna rezonanca}

Kod izraženih hidronefroza sa veoma oštećenom bubrežnom funkcijom, a pogotovo kod pacijenata sa bilateralnom hidronefrozom, kada je teško odrediti diferencijalnu funkciju, čak i sa MAG-3 scintigrafijom, idikovana je urografija magnetnom rezonancom uz primenu kontrastnog sredstva (gadolinijum). MR je takođe indikovana i u slučajevima kada se na IVU bubreg ne može prikazati zbog izrazite dilatacije pijelokaliksnog sistema i redukovane funkcije. Koristeći kontrast, može se odrediti volumen parenhima i proceniti funkcija oštećenog, preostalog bubrežnog parenhima. $^{23,53}$

\section{6. LEČENJE HIDRONEFROZE}

Kliničko-patološke promene kod hidronefroze variraju od asimptomatskih formi sa minimalnim opstruktivnim lezijama i gotovo normalnom anatomskom slikom sabirnog sistema, do potpune afunkcije organa, koji je pretvoren u hidronefrotičnu kesu. U zavisnosti od patoanatomskog nalaza i kliničke slike primenjuju se različite metode lečenja. Lečenje tipične hidronefroze ima za cilj da sanira opstruktivnu leziju, koja ugrožava funkciju bubrega i izaziva bolove, infekciju i druge simptome bolesti.

Uzrok, vrsta i stepen hidronefroze značajno utiču na izbor metode lečenja. Minimalna, asimptomatska hidronefroza zahteva samo periodične kontrole bolesnika. Afunkcija bubrega sa hidronefrotičnom atrofijom parenhima leči se nefrektomijom. Simptomatska, progresivna hidronefroza leči se konzervirajućom operacijom. Bilateralna hidronefroza i opstrukcija na solitarnom bubregu imperativno nalažu konzervaciju bubrega.

Podatak o funkcionalnom stanju bubrega odlučujući je faktor za dalje lečenje. ${ }^{3,40}$

\section{CILJ RADA}

Ultrazvučnim pregledom se obično jednostavno dijagnostikuje hidronefroza. Značajno je što se $u$ isto vreme može proceniti stanje parenhima, jer se težina hidro- 
nefroze meri ne samo stepenom dilatacije pijelokaliksnog sistema, nego i količinom destruisanog/očuvanog parenhima.

Atrofija parenhima je neravnomerna i nije dovoljno izmeriti debljinu parenhima na jednom mestu, nego se mora sagledati parenhim u celini.

U ovom radu će se odrediti kvantitativni parametri, koji najbolje pokazuju funkcionalnu sposobnost bubrega. Pri tome su formulisani sledeći ciljevi :

1) Odrediti kvantitativne parametre dobijene ulstrasonografijom, koji su značajni za praćenje stanja bubrega sa hidronefrozom;

2) Proceniti povezanost bubrežne morfologije utvrđene ultrasonografijom i bubrežne funkcije dobijene scintigrafijom;

3) Proceniti doprinos ultrasonografije u terapijskom pristupu rešavanja problema hidronefroze i praćenju efekata terapije.

\section{MATERIJAL I METODE}

\section{MATERIJAL}

\section{1. MESTO ISPITIVANJA}

Ispitivanje je sprovedeno u službi nuklearne medicine Instituta za štitastu žlezdu i metabolizam na Zlatiboru.

\section{2. VREME ISPITIVANJA}

Ispitivanje je trajalo u vremenskom periodu od maja 2003. god. do aprila 2004. god.

\section{ISPITIVANI UZORAK}

Ispitivanje je urađeno kod 35 pacijenata sa prethodno dijagnostikovanom hidronefrozom, upućenih u Institut, u službu nuklearne medicine, radi scintigrafije.

Ispitivane osobe su bile starosne dobi od 14 do 77 godina. U odnosu na pol 20 ispitanika je bilo ženskog, a 15 ispitanika muškog pola.

U studiju su uključeni samo pacijenti sa oba bubrega, a osim hidronefroze nije bilo drugih fokalnih promena na bubrezima (ciste, tumori, parenhimska oboljenja).

Svi pacijenti su imali normalnu vrednost kreatinina u serumu. 


\section{METODE}

\section{1. STATIČKA SCINTIGRAFIJA BUBREGA POMOĆU ${ }^{99 m}$ Tc-DIMERKAPTOSUKCINILNE KISELINE (DMSA)}

Svim pacijentima (i sa unilateralnom i sa bilateralnom hidronefrozom) urađena je statička scintigrafija bubrega pomoću DMSA obeleženog 99m tehnecijum pertehnetatom.

Obeleženi DMSA u dozi od $74 \mathrm{MBq}$ je injiciran intravenski.

Scintigrafija je rađena gama scintilacionom kamerom širokog vidnog polja Siemens Orbiter 37. Gama kamera je on-line povezana sa računarom Siemens Micro Delta. Amplitudni analizator je podešavan za rad u energetskom rasponu ${ }^{99 \mathrm{~m}} \mathrm{Tc}(140$ $\mathrm{keV}$ ) sa širinom prozora $20 \%$.

Korišćen je niskoenergetski kolimator sa paralelnim otvorima, univerzalne namene (LEAP-low energy all purpose).

Scintigrafija je rađena 2-4 sata nakon injiciranja obeleženog DMSA, jer se u to vreme dobijaju najkvalitetniji snimci kore bubrega, prikupljanjem 300000 impulsa po slici.

Osim standardnih snimaka u postero-anteriornoj (PA) projekciji u stojećem ili sedećem položaju, rađeni su snimci u antero-posteriornoj (AP) projekciji i dodatni snimci u desnom, odnosno levom bočnom (polukosom) položaju.

Scintigrafija se radi u sedećem ili stojećem položaju da bi se otkrile anatomske varijacije položaja, odnosno mobilnost bubrega.

Da bi se odredila dubina bubrega, može se kod lateralnih scintigrama označiti površina kože tačkastim izvorom ili radioaktivnim markerom. Dubina bubrega je rastojanje između centra bubrežne siluete sa scintifotografije i tačkastog izvora na površini leđa. Kod većine osoba bubrezi su smešteni na $9-10 \mathrm{~cm}$ od dorzalne površine tela. U prosečno $75 \%$ osoba bubrezi se nalaze na približno jednakoj dubini, odnosno razlika njihovog položaja ne prelazi $1,5 \mathrm{~cm}$. Posebno je značajno izvršiti korekciju na dubinu bubrega kada se vrši određivanje separatne bubrežne funkcije.

Dopunski lateralni scintigrami bubrega služe za preciznije određivanje veličine bubrega i za bolje prikazivanje ,ispada" unutar bubrežne siluete, odnosno za dobijanje dodatnih informacija o veličini, prostornom rasporedu i broju tih lezija.

Scintigram normalnog bubrega dobrog kvaliteta karakteriše se jasno ocrtanom kortikalnom morfologijom. Periferni deo bubrežne siluete ravnomerno i intenzivno nakuplja ${ }^{99 m}$ Tc-DMSA, a rubovi bubrežnih kontura su glatki i oštro ocrtani. Kora bubrega okružuje 4-8 relativno ,hipoaktivnih” područja koja se zrakasto pružaju ka centralnim delovima bubrega, a oivičena su nešto intenzivnijim aktivitetom piramidalnog ili polulučnog oblika. Ove hiperaktivne ,pregrade” najverovatnije odslikavaju 
kortikalne Bertinijeve kolumne, koje prodiru u „hladnu” medulu, čije strukture ne nakupljaju DMSA. Važno je ove detalje prepoznati i ne proglašavati ih patološkim promenama.

Na osnovu statičkog scintigrama bubrega može se proceniti položaj, oblik i veličina bubrega i regionalna distribucija funkcionalno aktivne mase kortikalnih nefrona.

Zdravi delovi parenhima se prikazuju kao područja intenzivne radioaktivnosti u poređenju sa područjima sa smanjenom funkcijom, koja vezuju manje radioaktivnosti, a potpuno afunkcionalni delovi parenhima uopšte neće nakupljati radioobeleživač, pa će se prikazati kao regije zantno smanjene ili potpuno odsutne radioaktivnosti.

Pored prikaza regionalnog rasporeda funkcionalne mase kore bubrega, scintigrafijom pomoću DMSA je svakom pacijentu kvantitativno određena i relativna separatna funkcija bubrega.

Pod relativnom funkcijom pojedinog bubrega podrazumeva se doprinos levog i desnog bubrega ukupnoj funkciji, odnosno raspodela ukupne bubrežne funkcije između para bubrega.

Iz međusobnog odnosa geometrijske srednje vrednosti broja impulsa u regijama od interesa oba bubrega, korigovanih na osnovnu radioaktivnost tela, sa korekcijom na dubinu bubrega i normalizovanih na površinu regiona od interesa svakog bubrega, izračunava se pomoću računarskog programa njihova relativna funkcija pomoću jednačine koja glasi :

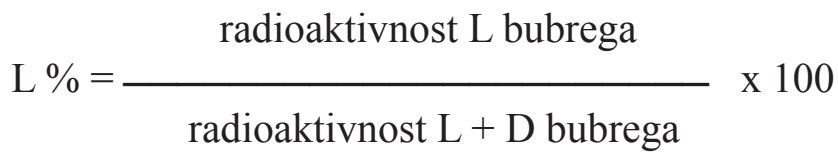

Donja granica normalne vrednosti relativnog nakupljanja ${ }^{99 \mathrm{~m}} \mathrm{Tc}-\mathrm{DMSA}$ (relativna kortikalna masa) individualnog bubrega je $42 \%$, a gornja $58 \%$.

Osim statičke scintigrafije bubrega, većini pacijenata je urađena i dinamska scintigrafija pomoću ${ }^{99 \mathrm{~m} T c-D T P A}$. Snimanje je rađeno tokom 20 minuta, u ležećem posteriornom položaju i to 80 sekvencijalnih sličica u trajanju od 15 sekundi. Rezultati dinamske scintigrafije su prikazani u obliku sekvencijalnih scintigrama i kompjuterizovanih radiorenograma.

\section{2. ULTRAZVUK}

Svim ispitanicima je urađen ultrazvučni pregled bubrega nakon pražnjenja mokraćne bešike.

Pregled je rađen real-time aparatom Aloka 500, sa konveksnom sondom od 3,5 $\mathrm{MHz}$, vodeći računa da se predeo koji pregledamo nalazi u fokusnoj zoni. 
Tehnika pregleda levog i desnog bubrega se međusobno razlikuju zbog različitih anatomskih odnosa.

Pregled desnog bubrega najčešće se počinje sa prednje strane, kod pacijenta u dorzalnom dekubitusu u zadržanom maksimalnom inspirijumu, kada jetra gotovo potpuno prekriva predeo bubrega potiskujući creva naniže i služi kao akustički prozor. Ukoliko prikaz celog bubrega nije moguć sa prednje strane (visok položaj kolona i meteorizam) koristi se bočni interkostalni i subkostalni pristup. Za ovo je ponekad potrebno okrenuti pacijenta u levi bočni dekubitus.

Levi bubreg se prednjim pristupom vidi znatno teže, zato za pregled levog bubrega, pacijenta postavljamo u desni dekubitus, a sondu polažemo na levi bok subkostalno, a po potrebi i interkostalno.

Ponekad se koriste i dorzalni pristupi pregledu bubrega pacijenta koji leži na trbuhu. Kod odraslih osoba ovaj pristup je nepovoljan zbog smetnji koje pravi dvanaesto rebro i uglavnom se koristi kod pregleda dece.

Rađeni su longitudinalni i transverzalni preseci bubrega. Evidentirani su dilatacija pijelokaliksnog sistema, a kod parenhima bubrega ocenjivani su kvantitet i očuvanost unutrašnje ehostrukture (diferencijacija korteksa i medule i stepen njihove ehogenosti).

Da bi merenje bubrega bilo verodostojno slika mora biti tako podešena da su sve strukture bubrega dobro prikazane, a naročito krajnji delovi. Kod merenja veličine bubrega oznaku za merenje treba postaviti svojim centrom na spoljni rub kapsule bubrega. Osim toga pri pravljenju uzdužnih i poprečnih preseka moramo biti sigurni da smo za merenje uzeli preseke sa zaista najvećim promerima. Kada je potrebno precizno merenje korisno je ponoviti merenje više puta i uzeti u obzir najveći dobijeni rezultat.

Pri ultrazvučnom pregledu izvršena su sledeća merenja :

1.) na transverzalnom preseku hidronefrotično izmenjenog bubrega $i$ to interpolarno na mestu gde je pijelon najširi meren je:

- anteroposteriorni dijametar pijelona. Na osnovu dobijenih vrednosti i karakeristika parenhima, određen je stepen hidronefroze;

2.) na maksimalnom longitudinalnom preseku mereni su:

- ukupna dužina bubrega (i normalnih kontralateralnih i bubrega sa hidronefrozom);

- bipolarna debljina parenhima (debljina parenhima gornjeg pola plus debljina parenhima donjeg pola) kod svih bubrega;

- površina parenhima kod svih bubrega i

- površina pijelokaliksnog sistema kod bubrega sa hidronefrozom.

Površina parenhima i površina pijelokaliksnog sistema se meri na longitudinalnom preseku na kome se vidi i maksimalna dužina i maksimalna širina bubrega. 
Merenje površine se vrši automatski ocrtavanjem obima bubrega i pijelokaliksnog sistema. Na aparatu na kome je rađeno merenje površina se izračunava ocrtavanjem regiona u obliku elipse.

Kod bubrega sa dilatiranim pijelokaliksnim sistemom, površina parenhima se dobije kada se od površine celog bubrega oduzme površina pijelokaliksnog sistema. Kod normalnih bubrega, bez dilatacije pijelokaliksnog sistema površina parenhima je jednaka površini celog bubrega.

Sva merenja su vršena od strane jednog ispitivača (autora ovog rada).

Dobijeni podaci su upoređeni sa diferencijalnom bubrežnom funkcijom dobijenom pri statičkoj scintigrafiji pomoću ${ }^{99 \mathrm{~m}} \mathrm{Tc}-\mathrm{DMSA}$.

Da bi se poređenje moglo izvršiti izračunavaju se sledeći paremetri:

- diferencijalna površina parenhima po formuli :

površina parenhima L bubrega

$\mathrm{L}(\%)=\longrightarrow \times 100$

površina parenhima $\mathrm{L}+\mathrm{D}$ bubrega

- diferencijalna dužina bubrega po formuli:

dužna L bubrega

$\mathrm{L}(\%)=\frac{}{\text { dužina } \mathrm{L}+\mathrm{D} \text { bubrega }} \times 100$

- diferencijalna bipolarna debljina parenhima po formuli:

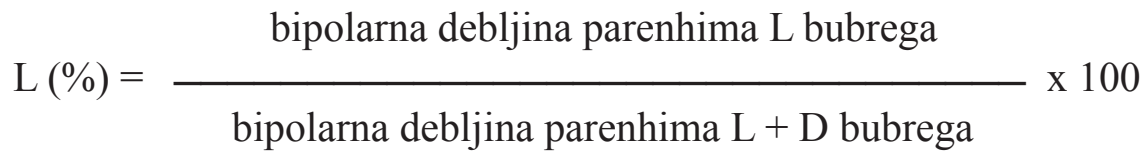

Osim toga izračunava se i odnos površine parenhima i površine pijelokaliksnog sistema.

\section{3. STATISTIČKE METODE}

Rezultati dobijeni u ovoj studiji opisani su klasičnim metodama deskriptivne statistike, odnosno od mera centralne tendencije korišćene su aritmetička sredina i medijana, a od mera varijabiliteta standardna devijacija i koeficijent varijacije. 
Od analitičkih metoda za procenu značajnosti razlike korišćeni su: Student-ov t test, test sume rangova, hi kvadrat test i Fišer-ov test tačne verovatnoće. Za procenu značajnosti povezanosti korišćeni su: koeficijent linearne korelacije i Spirman-ov koeficijent korelacije ranga.

Nivo značajnosti u svim korišćenim analitičkim metodama bio je na granici od 0,05.

\section{REZULTATI}

Ovom studijom je obuhvaćeno 35 pacijenata sa unilateralnom ili bilateralnom hidronefrozom (ukupno 70 bubrega). Svim pacijentima je urađena statička scintigrafija bubrega pomoću DMSA i ultrasonografija, u većini slučajeva istoga dana.

Stepenovanje hidronefroze je urađeno na osnovu ultrasonografskih karakteristika - AP dijametar pijelona i kvantitet i kvalitet parenhima.

Pacijenti su podeljeni u dve grupe :

Grupu 1 su činili pacijenti sa unilateralnom ili bilateralnom hidronefrozom I i II stepena. Grupu 2 su činili pacijenti sa unilateralnom hidronefrozom III i IV stepena i pacijenti sa bilateralnom hidronefrozom, pri čemu je na bar jednom bubregu bila hidronefroza III ili IV stepena.

- U ovim grupama od ukupno 35 pacijenata, 20 ispitanika je bilo ženskog, a 15 ispitanika muškog pola.

Tabela 1a. Distribucija ispitanika u odnosu na pol

\begin{tabular}{|l|c|c|}
\hline POL & BROJ ISPITANIKA & $\%$ \\
\hline ženski & 20 & 57 \\
muški & 15 & 43 \\
\hline UKUPNO & 35 & 100 \\
\hline
\end{tabular}

Tabela 1b. Značajnost razlike učestalosti ispitanika u odnosu na pol

\begin{tabular}{|c|c|c|c|cr|c|c|}
\hline \multicolumn{2}{|c|}{ POL } & \multirow{2}{*}{$\begin{array}{c}\text { STATISTIČKI } \\
\text { METOD }\end{array}$} & \multicolumn{3}{|l|}{ REZULTAT STATISTIČKE OBRADE } \\
\cline { 1 - 4 }$\check{z}$ & $\mathrm{~m}$ & ukupno & $\begin{array}{c}\text { Dobijena vrednost } \\
\text { empirijska teoretska }\end{array}$ & DF & $\begin{array}{c}\text { Verovatnoća } \\
\text { nulte hipoteze }\end{array}$ \\
\hline 20 & 15 & 35 & hi kvadrat & 0,456 & 3,841 & 1 & $\mathbf{p}>\mathbf{0 , 0 5}$ \\
\hline
\end{tabular}

Dobijeni rezultat pokazuje da ne postoji statistički značajna razlika ispitanika u odnosu na pol, odnosno da se u ovoj grupi muški i ženski pol pojavljuju približno podjednako.

- Ispitanici ove studije su bili starosti od 14 do 77 godina. 
Tabela 2a. Distribucija ispitanika u odnosu na životnu dob

\begin{tabular}{|c|c|c|}
\hline ŽIVOTNA DOB & BROJ ISPITANIKA & $\%$ \\
\hline $10-19$ & 2 & 6 \\
$20-29$ & 3 & 8 \\
$30-39$ & 7 & 20 \\
$40-49$ & 9 & 26 \\
$50-59$ & 7 & 20 \\
$60-69$ & 5 & 14 \\
$70-79$ & 2 & 6 \\
\hline UKUPNO & 35 & 100 \\
\hline
\end{tabular}

Tabela 2b. Deskriptivni statistički parametri za vrednost životnog doba

\begin{tabular}{|c|c|c|c|c|}
\hline \multicolumn{5}{|c|}{ STATISTIČKI PARAMETRI } \\
\hline $\mathrm{n}$ & $\overline{\mathrm{x}}(\mathrm{god})$ & $\mathrm{sd}$ & $\mathrm{cv}(\%)$ & med (god) \\
\hline 35 & 45,14 & 15,27 & 33,83 & 45 \\
\hline
\end{tabular}

Tabela 2c. Značajnost razlike učestalosti ispitanika u odnosu na životnu dob

\begin{tabular}{|c|c|cc|c|c|}
\hline \multirow{2}{*}{$\mathrm{n}$} & \multirow{2}{*}{$\begin{array}{c}\text { STATISTIČKI } \\
\text { METOD }\end{array}$} & \multicolumn{4}{|c|}{ REZULTAT STATISTIČKE OBRADE } \\
\cline { 3 - 6 } & $\begin{array}{c}\text { Dobijena vrednost } \\
\text { empirijska teoretska }\end{array}$ & DF & $\begin{array}{c}\text { Verovatnoća } \\
\text { nulte hipoteze }\end{array}$ \\
\hline 35 & hi kvadrat & 9,200 & 12,592 & 6 & $\mathbf{p}>\mathbf{0 , 0 5}$ \\
\hline
\end{tabular}

U odnosu na životnu dob ispitanici su podeljeni u sedam grupnih intervala, širine 10 godina. Analiza je pokazala da se broj ispitanika u tim intervalima statistički značajno ne razlikuje.

- Pošto su studijom obuhvaćene uglavnom odrasle osobe, najčešći uzrok hidronefroze je bila kalkuloza.

Tabela 3a. Distribucija ispitanika u odnosu na etiologiju hidronefroze

\begin{tabular}{|l|c|c|}
\hline ETIOLOGIJA HIDRONEFROZE & BROJ ISPITANIKA & $\%$ \\
\hline kalkuloza & 18 & 51 \\
stenoza UP segmenta & 4 & 11 \\
vaskularna opstrukcija & 2 & 6 \\
hidronefr.posle histerektomije & 2 & 6 \\
nepoznat uzrok & 9 & 26 \\
\hline UKUPNO & 35 & 100 \\
\hline
\end{tabular}


Tabela 3b. Značajnost razlike učestalosti ispitanika prema etiologiji hidronefroze

\begin{tabular}{|c|c|c|c|c|}
\hline \multirow[b]{2}{*}{$\mathrm{n}$} & \multirow[b]{2}{*}{$\begin{array}{l}\text { STATISTIČKI } \\
\text { METOD }\end{array}$} & \multicolumn{3}{|c|}{ REZULTAT STATISTIČKE OBRADE } \\
\hline & & \begin{tabular}{cc}
\multicolumn{2}{c}{ Dobijena vrednost } \\
empirijska $\quad$ teoretska
\end{tabular} & $\mathrm{DF}$ & $\begin{array}{l}\text { Verovatnoća } \\
\text { nulte hipoteze }\end{array}$ \\
\hline 35 & hi kvadrat & 13,277 & 4 & $\mathbf{p}<\mathbf{0 , 0 1}$ \\
\hline
\end{tabular}

Analiza distribucije ispitanika prema etiologiji hidronefroze pokazuje visoko statistički značajnu razliku.

- U studiju su uključeni i pacijenti sa unilateralnom i sa bilateralnom hidronefrozom.

Tabela 4a. Distribucija ispitanika u odnosu na postojanje unilateralne ili bilateralne hidronefroze

\begin{tabular}{|l|c|c|}
\hline OBOLJENJE & BROJ ISPITANIKA & $\%$ \\
\hline unilateralna hidronefroza & 26 & 74 \\
bilateralna hidronefroza & 9 & 26 \\
\hline UKUPNO & 35 & 100 \\
\hline
\end{tabular}

Tabela 4b. Značajnost razlike učestalosti ispitanika u odnosu na postojanje unilateralne ili bilateralne hidronefroze

\begin{tabular}{|c|c|cc|c|c|}
\hline \multirow{2}{*}{$\mathrm{n}$} & \multirow{2}{*}{$\begin{array}{c}\text { STATISTIČKI } \\
\text { METOD }\end{array}$} & \multicolumn{4}{|c|}{ REZULTAT STATISTIČKE OBRADE } \\
\cline { 3 - 6 } & empirijska & teoretska & DF & $\begin{array}{c}\text { Verovatnoća } \\
\text { nulte hipoteze }\end{array}$ \\
\hline 35 & hi kvadrat & 7,314 & 6,635 & 1 & $\mathbf{p}<\mathbf{0 , 0 1}$ \\
\hline
\end{tabular}

Među ispitanicima, koji su obrađeni u ovoj studiji nađena je visoko satistički značajna razlika u učestalosti bolesnika sa unilateralnom i bilataralnom hidronefrozom, a ova razlika je nastala kao posledica znatno većeg broja pacijenata sa unilateralnom hidronefrozom.

Tabela 4c. Distribucija ispitanika sa unilateralnom hidronefrozom u odnosu na zahvaćenu stranu

\begin{tabular}{|l|c|c|}
\hline UNILATERALNA HIDRONEFROZA & BROJ ISPITANIKA & $\%$ \\
\hline levi bubreg & 11 & 42 \\
desni bubreg & 15 & 58 \\
\hline UKUPNO & 26 & 100 \\
\hline
\end{tabular}


Tabela 4d. Značajnost razlike učestalosti ispitanika u odnosu na stranu zahvaćenu hidronefrozom

\begin{tabular}{|c|c|cc|c|c|}
\hline \multirow{2}{*}{$\mathrm{n}$} & \multirow{2}{*}{$\begin{array}{c}\text { STATISTIČKI } \\
\text { METOD }\end{array}$} & \multicolumn{4}{|c|}{ REZULTAT STATISTIČKE OBRADE } \\
\cline { 3 - 6 } & empirijska & teroetska & DF & $\begin{array}{c}\text { Verovatnoća } \\
\text { nulte hipoteze }\end{array}$ \\
\hline 26 & hi kvadrat & 0,346 & 3,841 & 1 & $\mathbf{p}>\mathbf{0 , 0 5}$ \\
\hline
\end{tabular}

U ovoj studiji nije utvrđena statistički značajna razlika između strane na kojoj se nalazi oboleli bubreg, t.j. u ovoj grupi ispitanika se hidronefroza na desnom i levom bubregu pojavljuje približno jednako.

Tabela 5a. Najčešći simptomi i znaci hidronefroze

\begin{tabular}{|l|c|c|}
\hline SIMPTOMI I ZNACI & BROJ ISPITANIKA & $\%$ \\
\hline bol u lumbalnom predelu & 28 & 55 \\
znaci urinarne infekcije & 13 & 25 \\
hipertenzija & 8 & 16 \\
bez simptoma & 2 & 4 \\
\hline UKUPNO & 51 & 100 \\
\hline
\end{tabular}

Najčešći simptom na koji su se pacijenti žalili ili zbog kog su se javili na pregled bio je bol u slabinskom predelu. Neki od pacijenata su imali više simptoma, dok su neki bili bez simptoma.

- Kod unilateralne hidronefroze su na normalnom kontralateralnom bubregu izmereni dužina bubrega, bipolarna debljina i površina parenhima i upoređeni između osoba ženskog i muškog pola.

Tabela 6a. Deskriptivni statistički parametri za izmerene dimenzije normalnih bubrega

\begin{tabular}{|l|c|c|c|c|c|c|}
\hline \multirow{2}{*}{$\begin{array}{l}\text { IZMERENE } \\
\text { DIMEZIJE } \\
\text { BUBREGA }\end{array}$} & \multirow{2}{*}{ pol } & \multicolumn{5}{|c|}{ STATISTIČKI PARAMETRI } \\
\cline { 3 - 7 } & & $\mathbf{n}$ & $\overline{\mathbf{x}}$ & $\mathbf{s d}$ & $\mathbf{c v}(\%)$ & $\mathbf{m e d}$ \\
\hline \multirow{2}{*}{\begin{tabular}{l} 
Dužina bubrega $(\mathrm{cm})$ \\
\cline { 3 - 7 }
\end{tabular}} & $\check{z}$ & 15 & 11,49 & 0,83 & 7,22 & 11,30 \\
\cline { 2 - 7 } & $\mathrm{m}$ & 11 & 11,41 & 1,32 & 11,57 & 10,80 \\
\hline
\end{tabular}




\begin{tabular}{|l|c|c|c|c|c|c|}
\hline \multirow{2}{*}{$\begin{array}{l}\text { IZMERENE } \\
\text { DIMEZIJE } \\
\text { BUBREGA }\end{array}$} & \multirow{2}{*}{ pol } & \multicolumn{5}{|c|}{ STATISTIČKI PARAMETRI } \\
\cline { 3 - 7 } & & $\mathbf{n}$ & $\overline{\mathbf{x}}$ & $\mathbf{s d}$ & $\mathbf{c v}(\%)$ & med \\
\hline $\begin{array}{l}\text { Bipolarna debljina } \\
\text { parenhima (cm) }\end{array}$ & $\check{z}$ & 15 & 4,26 & 0,35 & 8,22 & 4,20 \\
\cline { 2 - 7 } & $\mathrm{m}$ & 11 & 4,19 & 0,63 & 15,04 & 4,20 \\
\hline $\begin{array}{l}\text { Površina parenhima } \\
\left(\mathrm{cm}^{2}\right)\end{array}$ & $\check{\mathrm{z}}$ & 15 & 54,19 & 6,10 & 11,26 & 55,00 \\
\cline { 2 - 7 } & $\mathrm{m}$ & 11 & 54,16 & 11,26 & 20,79 & 50,10 \\
\hline
\end{tabular}

Tabela 6b. Značajnost razlike izmerenih dimenzija bubrega između osoba ženskog i muškog pola

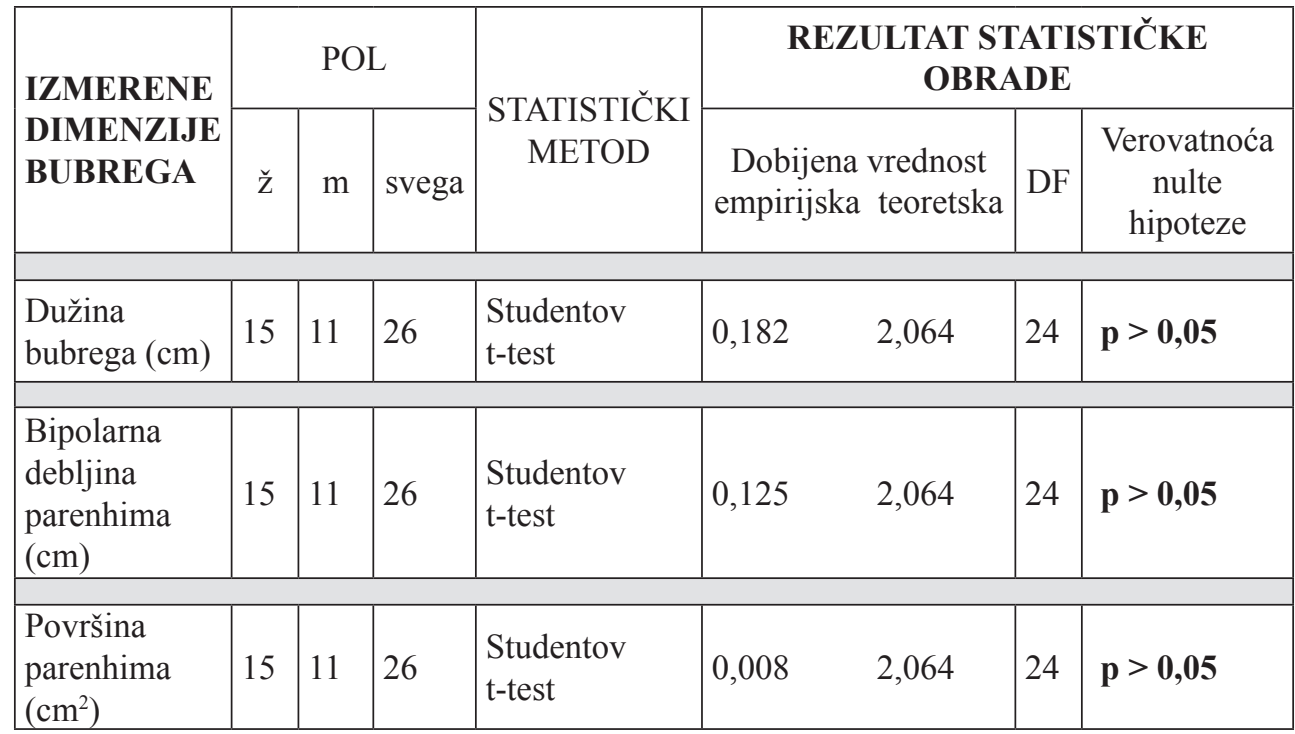

Analizom dobijenih podataka je utvrđeno da u ovoj grupi ispitanika ne postoje statistički značajne razlike u dimenzijama bubrega između osoba ženskog i muškog pola.

- Kod normalnih bubrega, kod grupe 1 (bubrezi sa hidronefrozom I-II stepena) i kod grupe 2 (bubrezi sa hidronefrozom III-IV stepena), međusobno su upoređeni rezultati jednodimenzionalnih (dužina bubrega i bipolarna debljina parenhima) i dvodimenzionalnih parametara (površina parenhima). 
Tabela 7a. Deskriptivni statistički parametri za US izmerene dimenzije bubrega, po kategorijama dijagnostičkih grupa

\begin{tabular}{|c|c|c|c|c|c|}
\hline \multirow{2}{*}{$\begin{array}{l}\text { IZMERENE DIMEZIJE } \\
\text { BUBREGA }\end{array}$} & \multicolumn{5}{|c|}{ STATISTIČKI PARAMETRI } \\
\hline & $\mathbf{n}$ & $\overline{\mathbf{x}}$ & sd & $\operatorname{cv}(\%)$ & med \\
\hline \multicolumn{6}{|l|}{ Normalni bubrezi } \\
\hline Dužina bubrega (cm) & 26 & 11,46 & 0,99 & 8,64 & 11,20 \\
\hline Bipolarna deb.par. (cm) & 26 & 4,23 & 0,48 & 11,35 & 4,20 \\
\hline Površina par. $\left(\mathrm{cm}^{2}\right)$ & 26 & 54,18 & 13,12 & 24,21 & 51,55 \\
\hline \multicolumn{6}{|l|}{ Hidronefroza I - II } \\
\hline Dužina bubrega (cm) & 26 & 11,27 & 0,96 & 8,52 & 11,35 \\
\hline Bipolarna deb.par. $(\mathrm{cm})$ & 26 & 3,99 & 0,48 & 12,03 & 3,95 \\
\hline Površina par. $\left(\mathrm{cm}^{2}\right)$ & 26 & 46,13 & 5,63 & 12,20 & 46,50 \\
\hline \multicolumn{6}{|l|}{ Hidronefroza III - IV } \\
\hline Dužina bubrega (cm) & 18 & 11,71 & 1,44 & 12,30 & 11,90 \\
\hline Bipolarna deb.par. (cm) & 18 & 2,11 & 0,84 & 39,81 & 2,20 \\
\hline Površina par. $\left(\mathrm{cm}^{2}\right)$ & 18 & 22,22 & 9,74 & 43,83 & 24,00 \\
\hline
\end{tabular}

Tabela 7b. Korelacija izmerenih parametara po kategorijama dijagnostičkih grupa

\begin{tabular}{|c|c|c|c|c|c|}
\hline \multirow{2}{*}{$\begin{array}{l}\text { IZMERENE } \\
\text { DIMEZIJE } \\
\text { BUBREGA }\end{array}$} & \multirow{2}{*}{$\mathbf{n}$} & \multirow{2}{*}{$\begin{array}{l}\text { STATISTIČKI } \\
\text { METOD }\end{array}$} & \multicolumn{3}{|c|}{ REZULTAT STATISTIČKE OBRADE } \\
\hline & & & $\begin{array}{c}\text { Dobijena vrednost } \\
\text { empirijska teoretska }\end{array}$ & DF & $\begin{array}{c}\text { Verovatnoća } \\
\text { nulte hipoteze }\end{array}$ \\
\hline \multicolumn{6}{|l|}{ Normalni bubrezi } \\
\hline $\begin{array}{l}\text { Dužina bub. i bipolarna } \\
\text { debljina parenhima }\end{array}$ & 26 & $\begin{array}{l}\text { koef. linearne } \\
\text { korelacije (r) }\end{array}$ & 0,496 & 24 & $\mathrm{p}<\mathbf{0 , 0 1}$ \\
\hline $\begin{array}{l}\text { Površina parenhima i } \\
\text { dužina bubrega }\end{array}$ & 26 & $\begin{array}{l}\text { koef. linearne } \\
\text { korelacije (r) }\end{array}$ & 0,589 & 24 & $\mathbf{p}<\mathbf{0 , 0 1}$ \\
\hline $\begin{array}{l}\text { Površina parenhima i } \\
\text { bipol.deb. parenhima }\end{array}$ & 26 & $\begin{array}{l}\text { koef. linearne } \\
\text { korelacije }(r)\end{array}$ & 0,439 & 24 & $\mathrm{p}<\mathbf{0 , 0 5}$ \\
\hline
\end{tabular}




\begin{tabular}{|c|c|c|c|c|c|c|}
\hline \multicolumn{7}{|l|}{ Hidronefroza I - II } \\
\hline $\begin{array}{l}\text { Dužina bub. i bipolarna } \\
\text { debljina parenhima }\end{array}$ & 26 & $\begin{array}{l}\text { koef. linearne } \\
\text { korelacije (r) }\end{array}$ & 0,098 & 0,388 & 24 & $p>0,05$ \\
\hline $\begin{array}{l}\text { Površina parenhima i } \\
\text { dužina bubrega }\end{array}$ & 26 & $\begin{array}{l}\text { koef. linearne } \\
\text { korelacije (r) }\end{array}$ & 0,579 & 0,496 & 24 & $\mathbf{p}<\mathbf{0 , 0 1}$ \\
\hline $\begin{array}{l}\text { Površina parenhima i } \\
\text { bipol.deb. parenhima }\end{array}$ & 26 & $\begin{array}{l}\text { koef. linearne } \\
\text { korelacije }(r)\end{array}$ & 0,633 & 0,496 & 24 & $\mathrm{p}<\mathbf{0 , 0 1}$ \\
\hline \multicolumn{7}{|l|}{ Hidronefroza III - IV } \\
\hline $\begin{array}{l}\text { Dužina bub. i bipolarna } \\
\text { debljina parenhima }\end{array}$ & 18 & $\begin{array}{l}\text { koef. korel. } \\
\text { ranga }\end{array}$ & $\begin{array}{l}\rho=- \\
t=0\end{array}$ & $5=2,120$ & 16 & $p>0,05$ \\
\hline $\begin{array}{l}\text { Površina parenhima i } \\
\text { dužina bubrega }\end{array}$ & 18 & $\begin{array}{l}\text { koef. korel. } \\
\text { ranga }\end{array}$ & $\begin{array}{r}\rho=0 \\
t=0,\end{array}$ & ${ }_{05}=2,120$ & 16 & $\mathrm{p}>\mathbf{0 , 0 5}$ \\
\hline $\begin{array}{l}\text { Površina parenhima i } \\
\text { bipol.deb. parenhima }\end{array}$ & 18 & $\begin{array}{l}\text { koef. korel. } \\
\text { ranga }\end{array}$ & $\begin{array}{r}\rho=0 \\
t=4\end{array}$ & $=2,921$ & 16 & $\mathbf{p}<\mathbf{0 , 0 1}$ \\
\hline
\end{tabular}

Kod normalnih bubrega je nađena visoko statistički značajna povezanost između dužine bubrega i bipolarne debljine parenhima i između površine i dužine bubrega. Statistički značajna povezanost je nađena između površine i bipolarne debljine parenhima.

Kod buberega sa hidronefrozom I-II stepena nađena je visoko statistički značajna povezanost između površine parenhima i dužine bubrega i između površine i bipolarne debljine parenhima. Između dužine bubrega i bipolarne debljine parenhima nije nađena statistički značajna povezanost.

U grupi bubrega sa hidronefrozom III-IV stepena nađena je visoko statistički značajna povezanost između površine i bipolarne debljine parenhima, dok između dužine bubrega i bipolane debljine parenhima i između površine parenhima i dužine bubrega nije nađena statistički značajna povezanost.

- Kod pacijenata sa unilateralnom ili bilateralnom hidronefrozom grupe $1 \mathrm{i}$ grupe 2 upoređeni su izračunati diferencijalni parametri iz ultrasonografski dobijenih mera sa diferencijalnom bubrežnom funkcijom dobijenom pri statičkoj scintigrafiji pomoću DMSA. U tabelama su navedeni parametri za onu stranu na kojoj je hidronefrotično izmenjen bubreg, kod unilateralne hidronefroze, odnosno za onu stranu na kojoj je bubreg sa većim stepenom, kod bilateralne hidroneforze. 
Tabela 8a. Deskriptivni statistički parametri za US izračunate parametre i za diferencijalnu bubrežnu funkciju dobijenu pri scintigrafiji (izraženi u procentima)

\begin{tabular}{|l|c|c|c|c|c|c|}
\hline \multirow{2}{*}{$\begin{array}{l}\text { DIFERENCIJALNI } \\
\text { PARAMETRI (\%) }\end{array}$} & \multicolumn{5}{|c|}{ STATISTIČKI PARAMETRI } \\
\cline { 2 - 7 } & $\mathbf{n}$ & $\overline{\mathbf{x}}$ & sd & cv (\%) & med \\
\hline Hidronefroza I - II & 17 & 51,06 & 2,46 & 4,82 & 51 \\
\hline Diferencijalna dužina bubrega & 17 & 49,23 & 3,14 & 6,38 & 49 \\
\hline $\begin{array}{l}\text { Diferencijalna bipolarna } \\
\text { debljina parenhima }\end{array}$ & 17 & 49,12 & 3,58 & 7,29 & 48 \\
\hline Diferencijalna površina parenhima & 17 & 49,94 & 3,93 & 4,87 & 49 \\
\hline Diferencijalna funkcija & & 18 & 50,22 & 3,81 & 7,58 & 52 \\
\hline Hidronefroza III - IV & 18 & 32,67 & 9,83 & 30,09 & 33,5 \\
\hline Diferencijalna dužina bubrega & 18 & 27,89 & 10,83 & 38,83 & 29 \\
\hline $\begin{array}{l}\text { Diferencijalna bipolarna } \\
\text { debljina parenhima }\end{array}$ & 18,17 & 14,41 & 57,25 & 25,5 \\
\hline Diferencijalna površina parenhima & 18 & & & \\
\hline Diferencijalna funkcija & & & & & \\
\hline
\end{tabular}

Tabela 8b. Korelacija diferencijalnih parametara izračunatih iz US izmerenih dimenzija $i$ diferencijalne bubrežne funkcije dobijene pri scintigrafiji, po kategorijama dijagnostičkih grupa

\begin{tabular}{|c|c|c|c|c|c|}
\hline \multirow{2}{*}{$\begin{array}{l}\text { DIFERENCIJALNI } \\
\text { PARAMETRI }\end{array}$} & \multirow{2}{*}{$\mathbf{n}$} & \multirow{2}{*}{$\begin{array}{l}\text { STATISTIČKI } \\
\text { METOD }\end{array}$} & \multicolumn{3}{|c|}{ REZULTAT STATISTIČKE OBRADE } \\
\hline & & & $\begin{array}{l}\text { Dobijena vrednost } \\
\text { empirijska teoretska }\end{array}$ & $\mathrm{DF}$ & $\begin{array}{c}\text { Verovatnoća } \\
\text { nulte } \\
\text { hipoteze }\end{array}$ \\
\hline \multicolumn{6}{|l|}{ Hidronefroza I - II } \\
\hline $\begin{array}{l}\text { Dif. dužina bubrega i } \\
\text { dif. funkcija }\end{array}$ & 17 & $\begin{array}{l}\text { koef. linearne } \\
\text { korelacije (r) }\end{array}$ & 0,482 & 15 & $p>0,05$ \\
\hline $\begin{array}{l}\text { Dif.bipol.deb. } \\
\text { parenhima i dif.funkcija }\end{array}$ & 17 & $\begin{array}{l}\text { koef. linearne } \\
\text { korelacije (r) }\end{array}$ & 0,623 & 15 & $\mathbf{p}<\mathbf{0 , 0 1}$ \\
\hline
\end{tabular}




\begin{tabular}{|l|c|l|l|l|c|}
\hline $\begin{array}{l}\text { Dif.površina parenhima } \\
\text { i dif.funkcija }\end{array}$ & 17 & $\begin{array}{l}\text { koef. linearne } \\
\text { korelacije }(\mathrm{r})\end{array}$ & $0,790 \quad 0,606$ & 15 & $\mathbf{p}<\mathbf{0 , 0 1}$ \\
\hline Hidronefroza III - IV \\
\hline $\begin{array}{l}\text { Dif. dužina bubrega i } \\
\text { dif. funkcija }\end{array}$ & 18 & $\begin{array}{l}\text { koeficijent } \\
\text { korel. ranga }\end{array}$ & $\begin{array}{l}\rho=0,211 \\
\mathrm{t}=0,861 \mathrm{t}_{0,05}=2,120\end{array}$ & 16 & $\mathbf{p}>\mathbf{0 , 0 5}$ \\
\hline $\begin{array}{l}\text { Dif.bipol.deb. } \\
\text { parenhima i dif.funkcija }\end{array}$ & 18 & $\begin{array}{l}\text { koeficijent } \\
\text { korel. ranga }\end{array}$ & $\begin{array}{l}\rho=0,812 \\
\mathrm{t}=7,491 \mathrm{t}_{0,01}=2,921\end{array}$ & 16 & $\mathbf{p}<\mathbf{0 , 0 1}$ \\
\hline $\begin{array}{l}\text { Dif.površina parenhima } \\
\text { i dif.funkcija }\end{array}$ & 18 & $\begin{array}{l}\text { koeficijent } \\
\text { korel. ranga }\end{array}$ & $\begin{array}{l}\rho=0,917 \\
\mathrm{t}=9,170 \mathrm{t}_{0,01}=2,921\end{array}$ & 16 & $\mathbf{p}<\mathbf{0 , 0 1}$ \\
\hline
\end{tabular}

U obe grupe bolesnika nađena je visoko statistički značajna korelacija između diferencijalne bipolarne debljine parenhima i diferencijalne bubrežne funkcije, kao i između diferencijalne površine parenhima i diferencijalne funkcije. Ni u jednoj grupi nije nađena statistički značajna korelacija između diferencijalne dužine bubrega i diferencijalne funkcije.

- Kod pacijenata sa unilateralnom hidronefrozom grupe 1 (I-II stepen hidronefroze) i grupe 2 (III-IV stepen hidronefroze) upoređeni su parametri izmereni na ultrasonografiji između hidronefrotično izmenjenog bubrega i kontralateralnog normalnog bubrega.

Tabela 9a. Deskriptivni statistički parametri za izmerene dimenzije hidronefrotično izmenjenog $i$ kontralateralnog, normalnog bubrega kod unilateralne hidronefroze

\begin{tabular}{|c|c|c|c|c|c|}
\hline \multirow{2}{*}{$\begin{array}{l}\text { IZMERENE DIMEZIJE } \\
\text { BUBREGA }\end{array}$} & \multicolumn{5}{|c|}{ STATISTIČKI PARAMETRI } \\
\hline & $\mathbf{n}$ & $\overline{\mathbf{x}}$ & sd & $\operatorname{cv}(\%)$ & med \\
\hline \multicolumn{6}{|l|}{ Hidronefroza I - II } \\
\hline Dužina bubrega (cm) & 9 & 11,50 & 1,34 & 11,65 & 11,70 \\
\hline Bipolarna deb.par. $(\mathrm{cm})$ & 9 & 4,10 & 0,44 & 10,73 & 4,00 \\
\hline Površina par. $\left(\mathrm{cm}^{2}\right)$ & 9 & 49,37 & 3,65 & 7,38 & 48,70 \\
\hline \multicolumn{6}{|c|}{ Kontralateralni normalan bubreg } \\
\hline Dužina bubrega $(\mathrm{cm})$ & 9 & 11,10 & 1,27 & 11,44 & 11,50 \\
\hline Bipolarna deb.par. $(\mathrm{cm})$ & 9 & 4,22 & 0,39 & 9,24 & 4,20 \\
\hline Površina par. $\left(\mathrm{cm}^{2}\right)$ & 9 & 51,89 & 9,63 & 18,56 & 48,60 \\
\hline \multicolumn{6}{|l|}{ Hidronefroza III - IV } \\
\hline Dužina bubrega (cm) & 17 & 11,76 & 1,50 & 12,75 & 12,00 \\
\hline Bipolarna deb.par. $(\mathrm{cm})$ & 17 & 2,09 & 0,88 & 42,11 & 2,20 \\
\hline
\end{tabular}




\begin{tabular}{|c|c|c|c|c|c|}
\hline Površina par. $\left(\mathrm{cm}^{2}\right)$ & 17 & 22,03 & 10,33 & 46,89 & 22,60 \\
\hline \multicolumn{6}{|c|}{ Kontralateralni normalan bubreg } \\
\hline Dužina bubrega $(\mathrm{cm})$ & 17 & 11,65 & 0,87 & 7,47 & 11,30 \\
\hline Bipolarna deb.par. (cm) & 17 & 4,24 & 0,53 & 12,47 & 4,20 \\
\hline Površina par. $\left(\mathrm{cm}^{2}\right)$ & 17 & 55,39 & 7,80 & 14,08 & 55,00 \\
\hline
\end{tabular}

Tabela 9b. Značajnost razlike izmerenih dimenzija pri US pregledu, hidronefrotično izmenjenog i kontralateralnog normalnog bubrega

\begin{tabular}{|c|c|c|c|c|c|c|c|c|}
\hline \multirow{2}{*}{$\begin{array}{l}\text { IZMERENE } \\
\text { DIMENZIJE } \\
\text { BUBREGA }\end{array}$} & \multicolumn{3}{|c|}{ n } & \multirow{2}{*}{$\begin{array}{l}\text { STATISTIČKI } \\
\text { METOD }\end{array}$} & \multicolumn{4}{|c|}{$\begin{array}{c}\text { REZULTAT STATISTIČKE } \\
\text { OBRADE }\end{array}$} \\
\hline & hidr. & nor. & svega & & $\begin{array}{r}\text { Dobijena } \\
\text { empirijska }\end{array}$ & $\begin{array}{l}\text { vrednost } \\
\text { teoretska }\end{array}$ & DF & $\begin{array}{c}\text { Verovatnoća } \\
\text { nulte } \\
\text { hipoteze }\end{array}$ \\
\hline \multicolumn{9}{|c|}{\begin{tabular}{|l|} 
Hidronefroza I - II \\
\end{tabular}} \\
\hline $\begin{array}{l}\text { Dužina } \\
\text { bubrega }(\mathrm{cm})\end{array}$ & 9 & 9 & 18 & $\begin{array}{l}\text { Studentov } \\
\text { t-test }\end{array}$ & 0,615 & 2,120 & 16 & $p>0,05$ \\
\hline $\begin{array}{l}\text { Bipolarna } \\
\text { debljina } \\
\text { parenhima } \\
(\mathrm{cm})\end{array}$ & 9 & 9 & 18 & $\begin{array}{l}\text { Studentov } \\
\text { t-test }\end{array}$ & 0,375 & 2,120 & 16 & $p>0,05$ \\
\hline $\begin{array}{l}\text { Površina } \\
\text { parenhima } \\
\left(\mathrm{cm}^{2}\right)\end{array}$ & 9 & 9 & 18 & $\begin{array}{l}\text { Studentov } \\
\text { t-test }\end{array}$ & 0,692 & 2,120 & 16 & $p>0,05$ \\
\hline \multicolumn{9}{|c|}{ Hidronefroza III - IV } \\
\hline $\begin{array}{l}\text { Dužina } \\
\text { bubrega }(\mathrm{cm})\end{array}$ & 17 & 17 & 34 & $\begin{array}{l}\text { Studentov } \\
\text { t-test }\end{array}$ & 0,256 & 2,037 & 32 & $p>0,05$ \\
\hline $\begin{array}{l}\text { Bipolarna } \\
\text { debljina } \\
\text { parenhima } \\
(\mathrm{cm}) \\
\end{array}$ & 17 & 17 & 34 & $\begin{array}{l}\text { test sume } \\
\text { rangova }\end{array}$ & $\sum \mathrm{R}=156,5$ & 223 & 32 & $\mathbf{p}<\mathbf{0 , 0 1}$ \\
\hline $\begin{array}{l}\text { Površina } \\
\text { parenhima } \\
\left(\mathrm{cm}^{2}\right)\end{array}$ & 17 & 17 & 34 & $\begin{array}{l}\text { test sume } \\
\text { rangova }\end{array}$ & $\sum \mathrm{R}=153$ & 223 & 32 & $\mathbf{p}<\mathbf{0 , 0 1}$ \\
\hline
\end{tabular}

Kod pacijenata sa unilateralnom hidronefrozom I-II stepena nije nađena statistički značajna razlika u dimenzijama hidronefrotično izmenjenog i kontralateralnog bubrega.

U grupi pacijenata sa unilateralnom hidronefrozom III-IV stepena nije nađena statistički značajna razlika u dužini bubrega, dok je razlika u bipolarnoj debljini i 
površini parenhima visoko statistički značajna između hidronefrotično izmenjenog i kontralateralnog bubrega.

- Kod pacijenata sa hidronefrozom I-II stepena i kod pacijenata sa hidronefrozom III-IV stepena izmeren je AP dijametar pijelona na maksimalnom transverzalnom, a površina pijelokaliksnog sistema na maksimalnom longitudinalnom ultrasonografskom preseku.

Osim toga, izračunat je odnos površine parenhima i površine pijelokaliksnog sistema za svaki hidronefrotično izmenjen bubreg.

Ove vrednosti su međusobno upoređene za svaku grupu posebno.

Tabela 10a. Deskriptivni statistički parametri za US izmerene i izračunate vrednosti dimenzija pijelokaliksnog sistema

\begin{tabular}{|l|c|c|c|c|c|}
\hline \multirow{2}{*}{ ISPITIVANI PARAMETAR } & \multicolumn{5}{|c|}{ STATISTIČKI PARAMETRI } \\
\cline { 2 - 7 } & $\mathbf{n}$ & $\overline{\mathbf{x}}$ & $\mathbf{s d}$ & $\mathbf{c v}(\%)$ & $\mathbf{m e d}$ \\
\hline Hidronefroza I - II & 26 & 2,06 & 0,56 & 27,18 & 2,100 \\
\hline AP dijametar pijelona (cm) & 26 & 6,43 & 4,59 & 71,36 & 5,100 \\
\hline površina pks (cm²) & 26 & 11,49 & 5,67 & 49,35 & 8,645 \\
\hline odnos površina parenhim/pks & 18 & 4,21 & 0,94 & 22,33 & 4,000 \\
\hline Hidronefroza III - IV & 18 & 34,71 & 16,66 & 47,99 & 28,500 \\
\hline AP dijametar pijelona (cm) & 18 & 0,82 & 0,50 & 60,98 & 0,735 \\
\hline površina pks (cm $\left.{ }^{2}\right)$ & & & & & \\
\hline odnos površina parenhim/pks & 18 &
\end{tabular}


Tabela 10b. Korelacija izmerenih i izračunatih parametara vezanih za dimenzije pijelokaliksnog sistema

\begin{tabular}{|c|c|c|c|c|c|}
\hline \multirow{2}{*}{$\begin{array}{l}\text { ISPITIVANI } \\
\text { PARAMETAR }\end{array}$} & \multirow[b]{2}{*}{$\mathbf{n}$} & \multirow{2}{*}{$\begin{array}{l}\text { STATISTIČKI } \\
\text { METOD }\end{array}$} & \multicolumn{3}{|c|}{ REZULTAT STATISTIČKE OBRADE } \\
\hline & & & $\begin{array}{l}\text { Dobijena vrednost } \\
\text { empirijska teoretska }\end{array}$ & DF & $\begin{array}{c}\text { Verovatnoća } \\
\text { nulte } \\
\text { hipoteze }\end{array}$ \\
\hline \multicolumn{6}{|l|}{ Hidronefroza I - II } \\
\hline $\begin{array}{l}\text { AP dijametar pijelona } \\
\text { i površina pks }\end{array}$ & 26 & $\begin{array}{l}\text { koeficijent } \\
\text { korel. ranga }\end{array}$ & $\begin{aligned} \rho & =0,878 \\
t & =8,969 \mathrm{t}_{0,01}=2,797\end{aligned}$ & 24 & $\mathrm{p}<\mathbf{0 , 0 1}$ \\
\hline $\begin{array}{l}\text { AP dijametar pijelona } \\
\text { i odnos površina par/ } \\
\text { pks }\end{array}$ & 26 & $\begin{array}{l}\text { koeficijent } \\
\text { korel. ranga }\end{array}$ & $\begin{array}{l}\rho=-0,790 \\
t=6,438 t_{0,01}=2,797\end{array}$ & 24 & $\mathrm{p}<\mathbf{0 , 0 1}$ \\
\hline $\begin{array}{l}\text { površina pks i odnos } \\
\text { površina par/pks }\end{array}$ & 26 & $\begin{array}{l}\text { koeficijent } \\
\text { korel. ranga }\end{array}$ & $\begin{array}{l}\rho=-0,930 \\
t=12,40 t_{0,01}=2,797\end{array}$ & 24 & $\mathbf{p}<\mathbf{0 , 0 1}$ \\
\hline \multicolumn{6}{|l|}{ Hidronefroza III - IV } \\
\hline $\begin{array}{l}\text { AP dijametar pijelona } \\
\text { i površina pks }\end{array}$ & 18 & $\begin{array}{l}\text { koeficijent } \\
\text { korel. ranga }\end{array}$ & $\begin{aligned} \rho & =0,817 \\
t & =5,663 \mathrm{t}_{0,01}=2,921\end{aligned}$ & 16 & $\mathbf{p}<\mathbf{0 , 0 1}$ \\
\hline $\begin{array}{l}\text { AP dijametar pijelona } \\
\text { i odnos površina par/ } \\
\text { pks }\end{array}$ & 18 & $\begin{array}{l}\text { koeficijent } \\
\text { korel. ranga }\end{array}$ & $\begin{array}{l}\rho=-0,593 \\
\mathrm{t}=2,946 \mathrm{t}_{0,01}=2,921\end{array}$ & 16 & $\mathrm{p}<\mathbf{0 , 0 1}$ \\
\hline $\begin{array}{l}\text { površina pks i odnos } \\
\text { površina par/pks }\end{array}$ & 18 & $\begin{array}{l}\text { koeficijent } \\
\text { korel. ranga }\end{array}$ & $\begin{array}{l}\rho=-0,773 \\
\mathrm{t}=4,871 \mathrm{t}_{0,01}=2,921\end{array}$ & 16 & $\mathbf{p}<\mathbf{0 , 0 1}$ \\
\hline
\end{tabular}

U ovom radu, u obe grupe ispitanika nađena je visoko statistički značajna korelacija sva tri parametra.

Odnos površine parenhim/pijelokaliksni sistem sa AP dijametrom pijelona i površinom pijelokaliksnog sistema je u obrnutoj srazmeri.

- Kod grupe pacijenata sa unilateralnom hidronefrozom I-II stepena i grupe sa hidronefrozom III-IV stepena upoređena je diferencijalna funkcija i odnos površina parenhim/pijelokaliksni sistem. 
Tabela 11a. Deskriptivni statistički parametri za diferencijalnu funkciju i odnos površina parenhim/pijelokaliksni sistem

\begin{tabular}{|l|c|c|c|c|c|c|}
\hline \multirow{2}{*}{ ISPITIVANI PARAMETAR } & \multicolumn{5}{|c|}{ STATISTIČKI PARAMETRI } \\
\cline { 2 - 7 } & $\mathbf{n}$ & $\overline{\mathbf{x}}$ & sd & cv (\%) & med \\
\hline Hidronefroza I -II & 9 & 50,78 & 2,78 & 5,48 & 50,00 \\
\hline diferencijalna funkcija (\%) & 9 & 12,89 & 8,95 & 69,43 & 10,33 \\
\hline odnos površina parenhim/pks & & & & & \\
\hline Hidronefroza III - IV & 17 & 24,29 & 14,38 & 59,20 & 25,00 \\
\hline diferencijalna funkcija (\%) & 17 & 0,79 & 0,48 & 60,76 & 0,67 \\
\hline odnos površina parenhim/pks & & & & \\
\hline
\end{tabular}

Tabela 11b. Korelacija diferencijalne funkcije i odnosa površina parenhim/pijelokaliksni sistem

\begin{tabular}{|l|c|c|c|c|c|}
\hline \multirow{2}{*}{$\begin{array}{l}\text { GRUPE } \\
\text { PACIJENATA }\end{array}$} & $\mathbf{n}$ & $\begin{array}{c}\text { STATISTIČKI } \\
\text { METOD }\end{array}$ & \multicolumn{3}{|c|}{ REZULTAT STATISTIČKE OBRADE } \\
\cline { 3 - 6 } & & $\begin{array}{c}\text { Dobijena vrednost } \\
\text { empirijska teoretska }\end{array}$ & DF & $\begin{array}{l}\text { Verovatnoća } \\
\text { nulte hipoteze }\end{array}$ \\
\hline Hidronefroza I - II & 9 & $\begin{array}{c}\text { koeficijent } \\
\text { korelacije ranga }\end{array}$ & $\rho=0,787 \quad 0,783$ & $\mathbf{p}<\mathbf{0 , 0 1}$ \\
\hline Hidronefroza III - IV & 17 & $\begin{array}{c}\text { koeficijent } \\
\text { korelacije ranga }\end{array}$ & $\begin{array}{c}\rho=0,697 \\
\mathrm{t}=3,888 \mathrm{t}_{0,01}=2,947\end{array}$ & 15 & $\mathbf{p}<\mathbf{0 , 0 1}$ \\
\hline
\end{tabular}

U obe grupe pacijenata dobijena je visoko statistički značajna korelacija između diferencijalne funkcije i odnosa površina parenhim/pijelokaliksni sistem.

- Donja granična vrednost diferencijalne bubrežne funkcije je $42 \%$, a većina autora navodi u svojim radovima da postoji redukcija parenhima ako je diferencijalna funkcija ispod $40 \%$. 
Tabela 12. Značajnost razlike učestalosti pacijenata sa diferencijalnom funkcijom jednakom ili manjom od 40\% $i$ većom od $40 \%$ u grupi pacijanata sa hidronefrozom I-II stepena $i$ hidronefrozom III-IV stepena

\begin{tabular}{|c|c|c|c|c|c|c|}
\hline \multirow{2}{*}{$\begin{array}{l}\text { DIFERENC. } \\
\text { FUNKCIJA }\end{array}$} & \multicolumn{3}{|c|}{ GRUPE } & \multirow{2}{*}{$\begin{array}{l}\text { STATISTIČKI } \\
\text { METOD }\end{array}$} & \multicolumn{2}{|c|}{$\begin{array}{c}\text { REZULTAT STATISTIČKE } \\
\text { OBRADE }\end{array}$} \\
\hline & 1 & 2 & svega & & $\begin{array}{l}\text { Dobijena vrednost } \\
\text { empirijska teoretska }\end{array}$ & $\begin{array}{l}\text { Verovatnoća } \\
\text { nulte hipoteze }\end{array}$ \\
\hline$\leq 40 \%$ & 0 & 14 & 14 & \multirow{2}{*}{$\begin{array}{l}\text { Fišerov } \\
\text { test tačne } \\
\text { verovatnoće }\end{array}$} & \multirow{2}{*}{$\mathrm{p}=0,00007$} & \multirow{2}{*}{$\mathrm{p}<0,01$} \\
\hline$>40 \%$ & 9 & 3 & 12 & & & \\
\hline ukupno & 9 & 17 & 26 & & & \\
\hline
\end{tabular}

Grupe ispitanika se visoko statistički značajno razlikuju po broju pacijenata sa diferencijalnom funkcijom jednakom ili manjom od $40 \%$ i većom od $40 \%$, pri čemu je kod svih pacijenata iz grupe 1 diferencijalna funkcija veća od $40 \%$. Na ovaj način se potvrđuje da u grupi sa hidronefrozom III-IV stepena postoji redukcija parenhima za razliku od grupe sa hidronefrozom I-II stepena.

- Osim kvantiteta posmatran je i kvalitet parenhima

Hiperehogen parenhim je uočen u bubrezima sa IV stepenom hidronefroze, koji su na DMSA scintigrafiji bili afunkcionalni.

U bubrezima sa hidronefrozom III stepena bila je normalna ehogenost parenhima, ali je kortiko-medularna granica bila nejasna.

U bubrezima sa hidronefrozom I-II stepena parenhim je bio normalne ehogenosti sa jasnom kortiko-medularnom granicom.

\section{DISKUSIJA}

Hidronefroza je jedno od najčešćih patoloških stanja koje se može utvrditi ultrasonografski. Ultrasonografija je obično inicijalni dijagnostički metod koji se primenjuje $\mathrm{u}$ ispitivanju urinarnog trakta. ${ }^{21}$

Opšte je poznato da dilatacija urinarnog trakta ne znači da uvek postoji opstrukcija i zbog toga je veoma značajno utvrditi koja hidronefroza je uzrokovana opstrukcijom i koja mora biti lečena operativno.

Klinički značajna opstrukcija se definiše kao restrikcija protoka urina, koja će ako se ne leči dovesti do progresivnog oštećenja bubrežnog parenhima. ${ }^{21}$ 
Dokazano je da povećan pritisak u pijelonu nastao zbog opstrukcije dovodi do bubrežne disfunkcije i oštećenja ćelija bubrežnog parenhima u toku vremena.

Zbog toga je potreban dijagnostički metod, koji je u mogućnosti da pruži objektivnu informaciju o promenama u bubregu, koje su posledica opstrukcije, pre nego što dođe do ireverzibilnog oštećenja. ${ }^{37}$

Trenutno ne postoji ,zlatni standard” tehnike koja može proceniti klinički značajnu opstrukciju i predvideti tok hidronefroze, pogotovu kod asimptomatskih pacijenata.

Jedini faktor koji je direktno povezan sa opstrukcijom je bubrežna funkcija. ${ }^{37}$

U upotrebi su različiti dijagnostički testovi za praćenje opstrukcije i osnovno je da oni budu pouzdani, efikasni i ekonomični.

Morfološke promene koje se uočavaju na ekskretornoj urografiji, kompjuterizovanoj tomografiji, ultrasonografiji i magnetnoj rezonanci su obično posledica opstrukcije, ali ne mogu same na osnovu jednog pregleda predvideti dalju progresiju redukcije bubrežne funkcije.

Za procenu postojanja klinički značajne opstrukcije, Whitaker je 1973. godine uveo u upotrebu test merenja pritiska u pijelonu u toku perfuzije tečnosti kroz perkutanu nefrostomu. Ovo je invazivan test i težak je za izvođenje, pa nije opšte prihvaćen kao rutinska metoda za procenu opstrukcije, nego se koristi u pojedinačnim slučajevima.

Diurezna renografija pomoću ${ }^{99 \mathrm{~m} T c-D T P A}$ ili ${ }^{99 \mathrm{~m} T c-M A G-3}$ je jednostavnija metoda. Klinički se primenjuje ne samo u dijagnostici opstrukcije, već i kao jedan od kriterijuma u postavljanju indikacija za operativno lečenje, kao i u posleoperativnoj proceni efekata hirurškog lečenja. U kliničkoj praksi operacija se sugeriše u slučajevima opstruktivne dilatacije, a konzervativno praćenje u slučajevima dilatiranog neopstruktivnog sabirnog sistema. ${ }^{13}$ Ponekad postoji problem kada je pijelokaliksni sistem izrazito dilatiran, a funkcija znatno oštećena, kao i kada se dobije granični, neopredeljiv (ekvivokalan) nalaz.

Osim postojanja znakova signifikantne opstruktivne dilatacije, značajan kriterijum za operativno lečenje je funkcija opstruiranog bubrega. ${ }^{30}$

Za procenu bubrežne funkcije koriste se metode nuklearne medicine.

Diferencijalna renalna funkcija dobijena bilo dinamskom, bilo statičkom scintigrafijom se najčešće koristi za procenu hidronefroze. Pri tome diferencijalna funkcija manja od $40 \%$ ili smanjene u toku praćenja je obično indikacija za operativno lečenje.

Dobijeni rezultati zavise od radiofarmaka koji se primenjuje, jer svaki meri različite aspekte bubrežne funkcije. ${ }^{40}$

U akutnoj opstrukciji hemodinamski pokazatelji funkcije bubrega (GFR, ERPF) ukazuju na težu disfunkciju nego DMSA statička studija. 
U hroničnoj opstrukciji hemodinamski pokazatelji su bolje očuvani od stepena očuvanosti relativne kortikalne mase, odnosno funkcionalne sposobnosti kortikalnih nefrona.$^{13}$

U većem broju radova je prikazano da ne postoji značajna razlika između diferencijalne bubrežne funkcije dobijene dinamskom scintigrafijom pomoću DTPA ili MAG-3 i diferencijalne funkcije dobijene statičkom scintigrafijom pomoću DMSA. ${ }^{60}$ Ipak smatra se da scintigrafija pomoću DMSA, zbog izvanredno visoke senzitivnosti daje bolji uvid u očuvanost funkcionalne bubrežne mase. ${ }^{30}$

Thompson sa saradnicima ${ }^{47}$ je izneo u svom radu značaj scintigrafije bubrega pomoću DMSA u predviđanju oporavka funkcije nakon operativnog lečenja stenoze UP segmenta. Regresionom analizom je utvrđeno da je preoperativna DMSA scintigrafija bila odličan prediktor rezultata operativnog lečenja, dok je preoperativni renogram bio znatno slabiji prediktor oporavka funkcije bubrega.

Kod praćenja bubrega pomoću DMSA scintigrafije bitno je na početku ispitivanja utvrditi da li je funkcija bubrega dobra ili loša, a zatim uočiti bilo kakvu promenu u toku vremena.

U ovom radu je za dobijanje uvida u funkcionalnu kortikalnu masu, kao i za određivanje diferencijalne funkcije bubrega korišćena ${ }^{99 \mathrm{~m} T c-D M S A}$ scintigrafija, a cilj rada je bio da se odrede najbolji kvantitativni parametri ultrasonografije bubrega, koji se mogu takođe primeniti u proceni funkcionalne sposobnosti bubrega sa hidronefrozom.

Ultrasonografija ima mnoge osobine koje je čine gotovo idealnom metodom za detekciju hidronefroze. Ona je neinvazivna, brza, ne koriste se radiografska kontrastna sredstva, niti jonizujuće zračenje i relativno je jeftina. ${ }^{38}$ Može se ponavljati, koristiti kod trudnica i kod pacijenata alergičnih na kontrastna sredstva.

Ultrazvuk pruža anatomske informacije o opstrukciji, u nekim slučajevima može se utvrditi nivo opstrukcije i uzrok, međutim ne daje fiziološke ili funkcionalne podatke o opstrukciji. ${ }^{38,53} \mathrm{O}$ funkciji bubrega na osnovu ultrazvučnog pregleda zaključuje se indirektno.

Ultrasonografija omogućava dobru vizualizaciju bubrežnog parenhima i dilataciju sabirnog sistema. Merenje maksimalnog dijametra pijelona na tranverzalnom preseku, kao i uočavanje dilatacije kaliksa, određivanje dužine bubrega sa hidronefrozom i dužine kontralateralnog bubrega, merenje debljine parenhima i uočavanje ehogenosti parenhima povećava mogućnost procene hidronefroze.

U ovom radu, pošto su ispitanici bili odrasle osobe, hidronefroza je klasifikovana u IV stepena na osnovu anteroposteriornog dijametra pijelona i debljine parenhima (kako je opisano u opštem delu str.21).

Većina radova iz oblasti hidronefroze odnosi se na novorođenčad i decu do dve godine starosti. 
Standardni testovi koji se koriste za ispitivanje hidronefroze kod odraslih osoba nemaju isti značaj kod dece. ${ }^{43}$

Stepeni hidronefroze na ultrasonografiji kod dece se određuju na osnovu uputstva za klasifikaciju Udruženja za fetalnu urologiju (Society for Fetal Urology - SFU) i to na sledeći način : 0 , normalan bubreg; 1 , diskretna dilatacija pijelona, bez dilatacije kaliksa; 2, umerena dilatacija pijelona i diskretna dilatacija kaliksa; 3 , znatno dilatiran pijelon i kaliksi sa očuvanim parenhimom; 4, veoma uvećan pijelon i kaliksi sa redukovanim parenhimom. ${ }^{23} 45$

U cilju bolje procene hidronefroze Cost i saradnici ${ }^{21}$ su razmotrili ultrasonografski izmerene parametre: longitudinalnu površinu parenhima i longitudinalnu površinu pijelokaliksnog sistema kod pacijenata sa hidronefrozom. Ove dvodimenzinalne parametre su uporedili sa standardnim jednodimenzionalnim merama dobijenim ultrasonografijom i sa diferencijalnom bubrežnom funkcijom dobijenom radiorenografijom (DTPA), kao i sa rezultatima ostalih kliničkih ispitivanja. Takođe su razmotrili mogućnost da se na osnovu ovih parametara predvidi pogoršanje bubrežne funkcije.

$\mathrm{U}$ ovom radu je izvršeno poređenje parametara dobijenih ultrasonografijom i parametara dobijenih statičkom scintigrafijom pomoću ${ }^{99 m}$ Tc-DMSA.

- DMSA scintigrafija i ultasonografija je urađena kod 35 ispitanika, pri čemu su u studiju uključeni samo oni pacijenti koji su imali oba bubrega (ukupno 70 bubrega). Osobe ženskog pola su bile zastupljenije u nešto većem procentu (57\%) u odnosu na ispitanike muškog pola (43\%), ali dobijeni rezultati statističke obrade pokazuju da nije postojala statistički značajna razlika ispitanika u odnosu na pol (tabela 1a i 1b).

U literaturi pri ispitivanju dece, nađeno je da se hidronefroza značajno češće javlja kod dečaka, nego kod devojčica. ${ }^{48,52}$

- Distribucija ispitanika u odnosu na životnu dob (tabela 2a) ukazuje da je najveća učestalost ispitanika bila u dobnoj kategoriji od 40 do 49 godina (26\%), a zatim u grupi od 30 do 39 i od 50 do 59 godina (po 20\%). Statističkom obradom nije nađena značajna razlika u odnosu na životnu dob (tabela $2 b$ ). Primenom aritmetičke sredine za različite frekvence pojavljivanja utvrđeno je da je prosečna starost u ispitivanoj grupi bila 45,14 godina.

- Analiza distribucije ispitanika prema etiologiji hidronefroze (tabela 3a) pokazuje visoko značajnu razliku u odnosu na 5 prisutnih kategorija (tabela $3 b$ ). Ova razlika je nastala kao posledica značajno većeg broja ispitanika sa kalkulozom kao uzrokom hidronefroze (51\%). Dve pacijentkinje su imale hidronefrozu nastalu nakon histerektomije, što je takođe opisano u literaturi. ${ }^{68}$ Najveći broj autora kao uzrok hidronefroze kod dece navodi stenozu UP segmenta.

- Analiza distribucije ispitanika u odnosu na postojanje unilateralne ili bilateralne hidronefroze pokazuje visoko značajnu razliku, zbog postojanja većeg broja ispitanika sa unilateralnom hidronefrozom i to $74 \%$ (tabela $4 a$ i 4b). 
Kod ispitanika sa unilateralnom hidronefrozom nije utvrđeno postojanje statistički značajne razlike u zahvaćenosti desnog ili levog bubrega (tabela 4c i 4d).

U radovima, koji ispituju hidronefrozu kod dece češća je unilateralna hidronefroza i to na levom bubregu. ${ }^{39,45,47,48,52}$

- Analiza distribucije ispitanika prema simptomima i znacima (tabela 5) pokazuje da je bol najčešći simptom (55\%) zbog koga se pacijenti obično i javljaju na pregled. U literaturi se navode slični simpromi: bol u slabinskom predelu, hematurija i ponavljane urinarne infekcije. ${ }^{47}$

Kinn ${ }^{36}$ je u svom radu navela da je pored kliničkih ispitivanja, odlučujuća indikacija za operativno lečenje bio stepen izraženosti simptoma hidronefroze i pojava komplikacija hidronefroze, od kojih je to najčešće bila infekcija, formiranje kalkulusa, perzistentni bolovi i hipertenzija.

- Pri ultrasonografiji pacijenata sa unilateralnom hidronefrozom dobijeni kvantitativni parametri (dužina bubrega, bipolarna debljina i površina parenhima) normalnih bubrega su upoređeni između ispitanika ženskog i muškog pola (tabela 6a). Rezultat statističke obrade (tabela 6 b) pokazuje da u ovoj studiji nije uočena razlika u veličini bubrega u odnosu na pol. U anatomiji se navodi da su bubrezi nešto većih dimenzija kod osoba muškog pola.

Yamazaki ${ }^{52}$ je pri određivanju dimenzija normalnih bubrega kod dece utvrdio statistički značajno veće dimenzije bubrega kod dečaka.

- U ovoj studiji su upoređeni jednodimenzionalni i dvodimenzionalni kvantitativni parametri dobijeni pri ultrasonografiji, da bi se zaključilo koji bolje mogu proceniti stanje parenhima.

U studiji je bilo 35 pacijenata, tj. izmereno je 70 bubrega. Mereni su: dužina bubrega, bipolarna debljina i površina parenhima. Kod ispitanika je bilo 26 normalnih bubrega (bez hidronefroze), 26 bubrega sa hidronefrozom I ili II stepena i 18 bubrega sa hidronefrozom III ili IV stepena (tabela 7a). Rezultati statističke obrade (tabela 7b) pokazuju kod normalnih bubrega i kod bubrega sa hidronefrozom I-II stepena dobru korelaciju jednodimenzinalnih mera (dužina bubrega i bipolarna debljina prenhima) sa dvodimenzionalnim merama (površina parenhima). Kod bubrega sa hidronefrozom III-IV stepena ne postoji značajna povezanost između dužine bubrega i površine parenhima, dok je povezanost između bipolarne debljine i površine parenhima visoko statistički značajna. Ne postoji značajna korelacija dužine bubrega i bipolarne debljine parenhima.

U toku progresije hidronefroze atrofija parenhima najjače je izražena u srednjim delovima bubrega, dok se u polovima ovaj proces odvija sporije. ${ }^{2} \mathrm{U}$ našoj studiji merenje debljine parenhima vršeno je na polovima bubrega.

Cost ${ }^{21}$ sa saradnicima u svom radu kod bubrega sa hidronefrozom III-IV stepena nije našao značajnu korelaciju između dužine bubrega i površine parenhima , kao ni 
između bipolane debljine i površine parenhima. Nije nađena značajna korelacija dužine bubrega i bipolarne debljine parenhima. Kod unilateralne hidronefroze, na normalnom kontralateralnom bubregu ovi autori su našli značajnu korelaciju između površine parenhima i dužine bubrega i između površine i bipolane debljine parenhima.

Prema tome jednodimenzionalne mere (dužina, debljina) pokazuju dobru korelaciju sa dvodimenzionalnim merama (površina) kod normalnih bubrega. Kod hidronefroze to nije slučaj t.j. postoji slaba korelacija dužine bubrega i površine parenhima. Bipolarna debljina parenhima pokazuje nešto bolju korelaciju sa površinom parenhima.

U literaturi se kao najčešći kriterijum za procenu stanja parenhima navodi merenje debljine parenhima. Procenjeno je da je debljina parenhima $\geq 1 \mathrm{~cm}$ dobar prognostički parametar. U hidronefrotično izmenjenom bubregu debljina parenhima je iregularna i merenje na jednom ili čak na nekoliko mesta ne ukazuje na stvarnu količinu funkcionalnog parenhima.

Shokeir ${ }^{40}$ je razmotrio ultrasonografsko merenje debljine parenhima i zaključio da se merenjem samo debljine parenhima može steći pogrešan utisak, jer je kod izrazite dilatacije pijelokaliksnog sistema parenhim razvučen oko dilatiranog i napetog sabirnog sistema i zbog toga je istanjen. Nakon otklanjanja opstrukcije debljina parenhima se može povećati, zbog toga takođe predlaže da se meri površina celog parenhima.

Sibai sa saradnicima ${ }^{48}$ je u retrospektivnoj studiji dokazao da bubrezi sa hidronefrozom IV stepena i difuznom atrofijom parenhima imaju lošiju funkciju od bubrega sa segmentnom atrofijom parenhima. Ultrasonografski se može vizualizovati parenhim, što daje korisne informacije za prognozu hidronefroze i odluku o načinu lečenja, ali je potrebno sagledati parenhim u celini.

Slična merenja maksimalne dužine bubrega i najveće longitudinalne površine je vršio i Yamazaki sa saradnicima ${ }^{52}$ i pri tome je zaključio da je merenje površine bubrega bolji indeks veličine bubrega, nego dužina.

Da bi se utvrdila stvarna količina parenhima, najbolje bi bilo meriti ne ni površinu, nego ukupan volumen bubrežnog parenhima. ${ }^{40}$

Merenje volumena parenhima je u današnje vreme znatno lakše zbog uvođenja u upotrebu novih $3 \mathrm{D}$ ultrazvučnih aparata. ${ }^{23,51,61}$

- U većini institucija diferencijalna bubrežna funkcija dobijena scintigrafijom je glavni parametar za procenu funkcionalne sposobnosti bubrega i na osnovu nje se indikuje način terapije hidronefroze.

Cost sa saradnicima ${ }^{21}$ je ultrasonografski izmerenu površinu parenhima bubrega uporedio sa diferencijalnom funkcijom dobijenom scintigrafijom. Ovo je bila korisna studija, jer je pokušano da se uporede morfološke studije sa funkcionalnim. Ponekad merenje površine parenhima može biti komplikovano, pogotovo ako postoji iregularna dilatacija sabirnog sistema. 
U našem radu su izvršena poređenja ultrasonografski dobijenih parametara sa diferencijalnom funkcijom dobijenom DMSA scintigrafijom.

Pacijenti sa hidronefrozom su podeljeni u dve grupe. Grupu 1 su sačinajvali pacijenti sa hidronefrozom I i II stepena, a grupu 2, pacijenti sa hidronefrozom III i IV stepena. Iz izmerenih ultrasonografskih vrednosti izračunati su diferencijalni parametri (na način kako je opisano u metodama) i upoređeni sa diferencijalnom funkcijom (tabela 8a i 8b). Rezultati statističke obrade pokazuju u obe grupe pacijenata da ne postoji statistički značajna korelacija između diferencijalne dužine bubrega i diferencijalne funkcije, a korelacija između diferencijalne bipolane debljine parenhima i diferencijalne funkcije i između diferencijalne površine parenhima i diferencijalne funckije je statistički visoko značajna.

Cost ${ }^{21}$ je kod bubrega sa hidronefrozom III-IV stepena našao visoko statistički značajnu korelaciju diferencijalne površine i diferencijalne funkcije. Nešto slabiju korelaciju je našao između diferencijalne bipolarne debljine parenhima i diferencijalne funkcije, dok korelacija diferencijalne dužine bubrega i diferencijalne funkcije nije bila statistički značajna.

Prema tome površina parenhima pokazuje dobru korelaciju sa relativnom bubrežnom funkcijom. Bazirajući se na ovim podacima može se zaključiti da je longitudinalna površina parenhima značajno pouzdanija u proceni veličine bubrega sa hidronefrozom nego dužina bubrega i bipolana debljina parenhima i da može validno proceniti diferencijalnu bubrežnu funkciju. ${ }^{21}$ Ova povećana preciznost je zbog mogućnosti da se u merenje uključi celokupan parenhim i da se pri merenju isključi dilatiran pijelokaliksni sistem. Merenje površine parenhima je indirektna mera bubrežne funkcije.

- Poređenjem veličine bubrega (ultrasnografski dobijeni parametri) između hiodronefrotično izmenjenog $\mathrm{i}$ kontralateralnog normalnog bubrega dobijeni su statističkom obradom sledeći rezultati: u grupi 1, pacijenata sa hidronefrozom I-II stepena nije nađena statistički značajna razlika u dužini bubrega, bipolarnoj debljini i površini parenhima između hidronefrotično izmenjenog i normalnog kontralateralnog bubrega. U grupi 2, pacijenata sa hidronefrozom III-IV stepena nije nađena statistički značajna razlika u dužini bubrega, dok je razlika u bipolarnoj debljini i površini parenhima visoko statistički značajna, t.j. veća je je kod normalnih bubrega (tabela 9a i 9b). Iz ovoga se može zaključiti da parenhim nije redukovan u hidronefrozi I i II stepena.

Cost i saradnici ${ }^{21}$ su u retrospektivnoj studiji uporedili ultrasonografske parametre između grupe pacijenata, koja nije planirana za operaciju i grupe planirane za operaciju. U grupi koja nije lečena operativno nisu našli značajnu razliku u površini parenhima, dok je dužina bila značajno veća kod hidronefrotično izmenjenog, a bipolarna debljina parenhima kod kontralateralnog bubrega. U grupi pacijenata kod kojih je planirana operacija nađena je značajno veća dužina hidronefrotičnog bubrega, dok je kod kontralateralnih nađena značajno veća površina i bipolana debljina parenhima. 
Stepen oštećenja parenhima jednostrano hidronefrotičnog bubrega indirektno se može proceniti na osnovu kompenzatorne hipertrofije kontralateralnog bubrega. ${ }^{21}$

- Da bi se utvrdilo koji parametar veličine pijelokaliksnog sistema ukazuje na težinu hidronefroze upoređeni su AP dijametar pijelona, površina pijelokaliksnog sistema i odnos površina parenhim/pijelokaliksni sistem (tabela 10a i 10b). U obe grupe pacijenata je nađena visoko statistički značajna korelacija između ovih parametara.

Sama dimenzija pijelokaliksnog sistema ne može uvek odrediti težinu hidronefroze, jer i manje dilatiran pijelon koji se nalazi intrarenalno može dovesti do većeg oštećenja parenhima, nego ekstremno dilatiran pijelon, koji je položen ekstrarenalno.

Cost ${ }^{21}$ je u svojoj retrospektivnoj studiji uporedio parametre vezane za dimenzije pijelokaliksnog sistema $u$ dve grupe pacijenata sa hidronefrozom III-IV stepena. Prvu grupu su činili pacijenti predviđeni za operativno lečenje stenoze UP segmenta, a drugu grupu pacijenti kod kojih nije indikovana operacija. Na osnovu AP dijametra pijelona i površine pijelokaliksnog sistema nisu se mogle precizno razgraničiti ove dve grupe, dok se poređenjem odnosa površina parenhim/pijelokaliksni sistem jasno mogla odvojiti grupa pacijenata predviđenih za pojeloplastiku od grupe koja je samo praćena. Pri tome granična vrednost odnosa površina parenhim/pijelokaliksni sistem je bila 1,6 .

Prema tome jednodimenzionalna merenja pijelokaliksnog sistema ne mogu tačno proceniti oštećenje parenhima i indikovati operativno lečenje. Nešto bolju procenu dobijamo dvodimenzionalnim merenjima, dok se stanje parenhima najbolje može proceniti pomoću odnosa površina parenhim/pijelokaliksni sistem. Postoje tri moguća razloga za bolju prediktivnu sposobnost ovog odnosa: 1.) odnos se zasniva na dvodimenzionalnim merenjima, koji omogućavaju tačniju procenu stvarnih dimenzija bubrega; 2.) na odnos ne utiču varijacije u dimenzijama bubrega između različitih pacijenata. AP dijametar pijelona od npr. 1,5 cm može biti značajan kod manjih osoba, sa manjim bubrezima; 3.) odnos se zasniva na merenjima na longitudinalnim sonografskim presecima bubrega, koji se pouzdanije dobijaju od transverzalnih preseka, potrebnih za merenje AP dijametra pijelona. Nedostatak ovih merenja je to što je potrebno više vremena da bi se ona izvršila.

Rodriguez sa saradnicima ${ }^{46}$ je takođe u retrospektivnoj studiji merila površinu parenhima i površinu pijelokaliksnog sistema, izračunavala odnos ovih površina i dobila jasnu granicu između pacijenata lečenih operativno od onih lečenih konzervativno. Kod operisanih pacijenata je taj odnos bio jednak ili manji od 1,6 u 96\% slučajeva.

Ostali autori opisuju različite načine merenja pijelokaliksnog sistema i određivanja težine hidronefroze: Imaji i Dewan ${ }^{45}$ su u retrospektivnoj studiji računali odnos dubine dilatiranog kaliksa i debljine parenhima na gornjem ili donjem polu bubrega, koji je bio veći kod većeg stepena hidronefroze; Kinn ${ }^{36}$ je merila širinu pijelona i vrata dilatiranih kaliksa. 
- Kod pacijenata sa unilateralnom hidronefrozom upoređena je diferencijalna bubrežna funkcija dobijena DMSA scintigrafijom i odnos površina parenhim/pijelokaliksni sistem kod grupe pacijenata sa hidronefrozom I-II stepena i kod grupe pacijenata sa hidronefrozom III-IV stepena (tabela 11a i 11b). Rezultat statističke obrade pokazuje visoko statistički značajnu povezanost ovih parametara u obe grupe pacijenata.

Rodrigue ${ }^{46}$ je takođe uporedila odnos površina parenhim/pijelokaliksni sistem sa diferencijalnom funkcijom i utvrdila korelaciju smanjenja ovog odnosa sa smanjenjem diferencijalne funkcije, kao i sa pogoršanjem stepena hidronefroze na ultrasonografiji. Kod pacijenata sa hidronefrozom II stepena ovaj odnos je bio veći od 4 .

- U literaturi je redukcija parenhima u hidronefrotičnom bubregu definisana kao relativna diferencijalna funkcija manja od $40 \%$. $30,42,43,48,66$

U ovom radu je statističkom obradom utvrđeno da se visoko statistički značajno razlikuje broj ispitanika sa diferencijalnom funkcijom većom od $40 \%$ i jednakom ili manjom od $40 \%$ u dve grupe pacijenata, zbog postojanja većeg broja pacijenata sa diferencijalnom funkcijom većom od $40 \%$ u grupi ispitanika sa hidronefrozom I-II stepena, odnosno većeg broja pacijenata sa diferencijalnom funkcijom jednakom ili manjom od $40 \%$ u grupi ispitanika sa hidronefrozom III-IV stepena (tabela 12a i 12b).

Konda sa saradnicima ${ }^{30}$ je takođe utvrdio korelaciju stepena hidronefroze određenog ultrasonografski sa značajnošću redukcije bubrežnog parenhima na DMSA scintigrafiji. Utvrđeno je da relativna separatna funkcija opada statistički značajno sa povećanjem stepena hidronefroze.

- Osim kvantiteta parenhima pri ultrasonografiji je potrebno oceniti i kvalitet t.j. očuvanost unutrašnje ehostrukture (diferencijacija korteksa i medule i stepen njihove ehogenosti).

Kod bubrega sa hidronefrozom I i II stepena parenhim je bio normalne ehogenosti. Kod hidronefroze III stepena korteks je bio uobičajene ehogenosti, ali je kortiko-medularna granica bila nejasna. Kod hidronefroza IV stepena korteks je bio povećane ehogenosti i u njemu se nisu prepoznavale piramide.

Kod pacijenata kod kojih je na scintigrafiji bubreg bio afunckionalan, na ultrasonografiji se uočavao parenhim, mada veoma istanjen i hiperehogen.

- Cilj terapije hidronefroze je očuvanje bubrežne funkcije.

Za procenu stanja bubrežnog parenhima najčešće se koristi diferencijalna renalna funkcija dobijena metodama nuklearne medicine. ${ }^{41,46,48,49} \mathrm{Za}$ sada ne postoje naučno utvrđene vrednosti diferencijalne funkcije na osnovu kojih će se doneti odluka o načinu lečenja. 
Kada je u pitanju hidronefroza I-II stepena, većina autora se slaže da je dovoljno praćenje ultrasonografijom i ako se uoči pogoršanje (povećanje dilatacije pijelokaliksnog sistema, atrofija parenhima) indikuje se scintigrafija. ${ }^{30,32,54}$

U slučajevima gde je funkcija veoma oslabljena predlaže se nefrektomija. Nivo redukcije još uvek nije jasno definisan, ali se u većini ustanova, za nefrektomiju odlučuju ako je diferencijalna funkcija manja od $10 \%{ }^{47}$. Odluka o nefrektomiji ne sme se bazirati samo na podacima dobijenim scintigrafijom, nego se i ostali faktori moraju uzeti u obzir, zbog toga se kombinuju različiti testovi. ${ }^{40}$ Ponekad je pre nefrektomije potrebno postaviti perkutanu nefrostomu i posmatrati ponašanje parenhima nakon uklanjanja opstrukcije. ${ }^{40,58}$ Nefrektomija se predlaže i u slučajevima često ponavljanih epizoda urinarne infekcije kod izražene hidronefroze, u slučajevima multiple kalkuloze i u slučajevima hipertenzije. ${ }^{36}$

Terapija umerene hidronefroze je još uvek sporna, osim u slučajevima signifikantne opstrukcije utvrđene diureznom renografijom, kada se predlaže operativno lečenje.

Kinn ${ }^{36}$ je u svom radu iznela zaključak da je hidronefroza umerenog stepena kod odraslih osoba u slučajevima kada nema infekcije ili multiple kalkuloze, prilično benigno stanje i da se ovi pacijenti mogu lečiti konzervativno, a operacija se indikuje kod pojave izraženih simptoma.

Problem je terapija hidronefroze kod dece do dve godine, jer se u većem broju bubrega u toku vremena može uočiti popravljanje funkcije ili povlačenje znakova hidronefroze. ${ }^{43}$

Koff sa saradnicima ${ }^{43}$ je utvrdio da je unilateralna hidronefroza dijagnostikovana prenatalno relativno benigno stanje i da je operacija potrebna u strogo izabranim slučajevima. I pored brojnih studija ostaje nejasno kakvo poboljšanje bubrežne funkcije se može očekivati nakon pijeloplastike i koji pacijenti će imati više koristi od neoperativnog lečenja.

Većina autora zbog toga predlaže konzervativni tretman, t.j. praćenje, ali kontrole moraju biti česte, preporučuju se na 3 meseca, a kod manje diferencijalne funkcije i ćešče. Ako se u to vreme dijagnostikuje pogoršanje i uradi operacija neće doći do ireverzibilnog oštećenja bubrežne funkcije. Ukoliko su intervali kontrolnih pregleda duži i ne uoči se na vreme pogoršanje hidronefroze, doći će do trajnog gubitka bubrežne funkcije, koja se ne popravlja posle operacije. ${ }^{23,34,42,43,48}$

Kao pogoršanje se navodi smanjenje diferencijalne funkcije za više od $10 \%$ između dve kontrole i ultrasonografsko povećanje stepena hidronefroze. ${ }^{40,43,48}$ Neki autori značajnom smatraju smanjene funkcije za 5\%..$^{4265}$

Praćenje je potrebno i nakon operacije. U većini slučajeva na ultrasonografiji se vidi dilatiran pijelon, ali je dilatacija manja i vremenom se još smanjuje, a debljina parenhima je kao i pre operacije. Na diureznoj renografiji se dobija dilatiran neopstruktivni odgovor. Na DMSA scintigrafiji se uočava poboljšanje funkcije. ${ }^{32} 39$ 


\section{ZAKLJUČAK}

1. Ultrasonografija je u današnje vreme primarna dijagnostička metoda za ispitivanje u urologiji. Omogućava izvanrednu anatomsku vizualizaciju bez jonizujućeg zračenja. Precizna je u dijagnozi hidronefroze, ali nije uvek u mogućnosti da definiše opstrukciju, a o bubrežnoj funkciji se može zaključiti indirektno.

2. Za dobijanje uvida u funkcionalnu kortikalnu masu, kao i za određivanje diferencijalne funkcije od velikog značaja je ${ }^{99 \mathrm{~m}}$ Tc-DMSA statička scintigrafija. Osim preoperativne evaluacije opstruiranog bubrega može se predvideti i stepen očekivanog oporavka bubrežne funkcije nakon lečenja.

3. Površina parenhima izmerena ultrasonografski omogućava tačniju procenu veličine i funkcije hidronefrotično izmenjenog bubrega, nego klasična jednodimenzionalna merenja (dužina bubrega i debljina parenhima).

4. Površina parenhima hidronefrotično izmenjenog bubrega dobro koreliše sa funkcijom bubrega dobijenom DMSA scintigrafijom.

5. Odnos površina parenhim/pijelokaliksni sistem je najbolji ultrasonografski dobijen parametar za procenu stanja parenhima bubrega.

6. Ultrasonografski se osim debljine parenhima uočava očuvanost unutrašnje ehostrukture na osnovu čega se posredno procenjuje funkcija parenhima.

7. Serijske ultrasonografske kontrole pacijenata, koji se tretiraju konzervativno su neinvazivne i mogu zameniti serijske scintigrafije, t.j. scintigrafija se ponavlja ako se na ultrasonografiji uoči pogoršanje hidronefroze.

8. Ultrasonografija je zbog neinvazivnosti i relativno niske cene pregleda, pogodna za dugotrajno postoperativno praćenje pacijenata.

9. Ultrasonografija i DMSA scintigrafija su komplementarne metode i svaka ima svoj doprinos u evaluaciji hidronefroze. 


\section{ILUSTROVANI DODATAK}

Normalan bubreg:
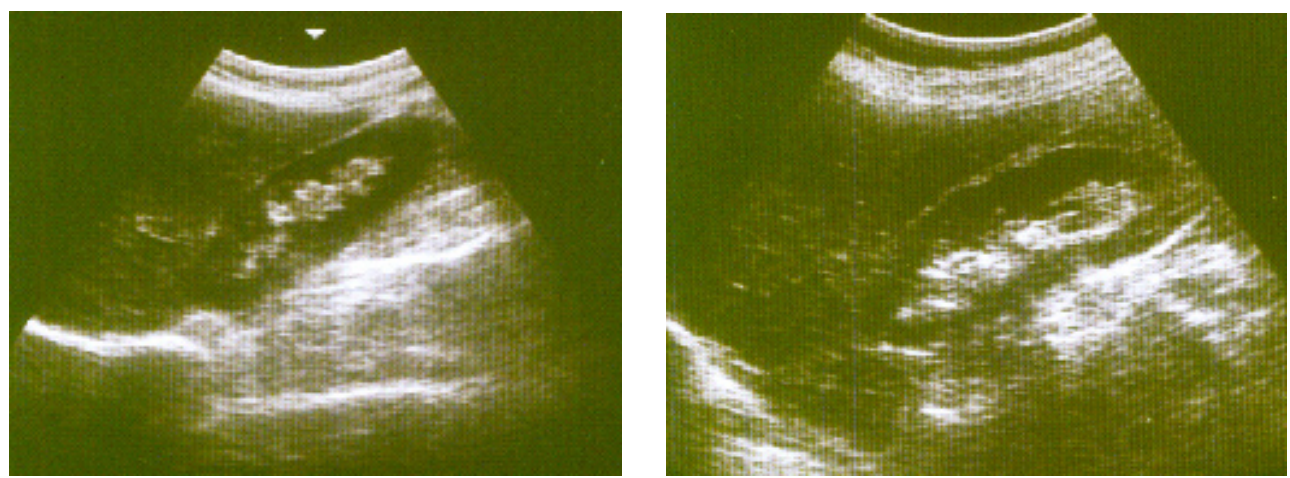

Ultrazvuk

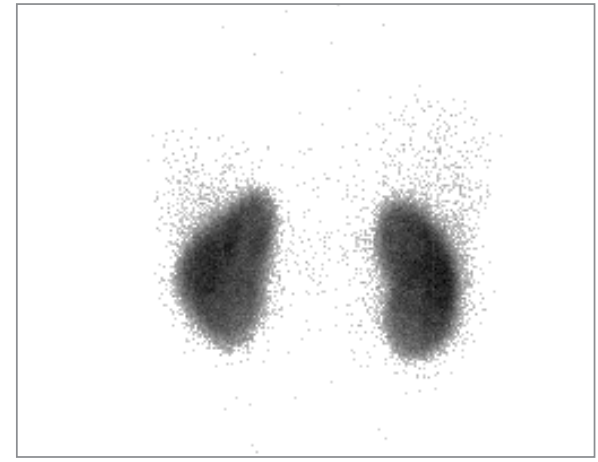

DMSA scintigram

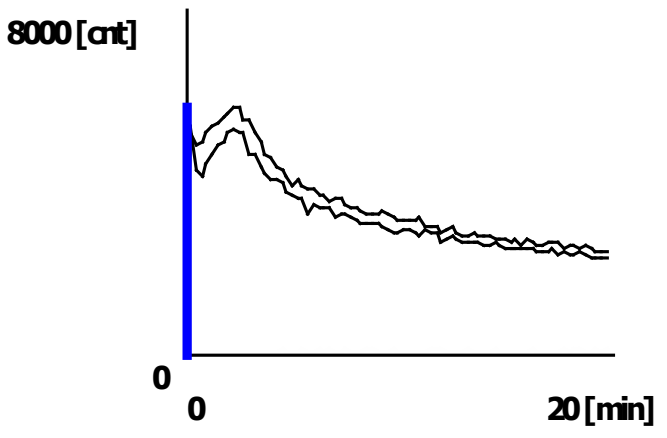

Radiorenogram 


\section{Hidronefroza I stepena:}
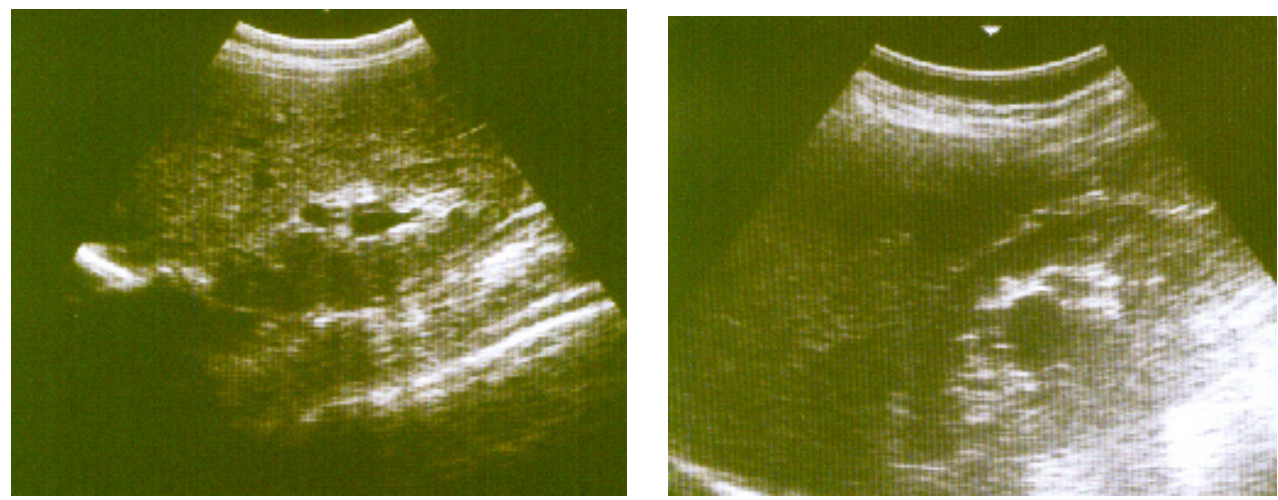

Ultrazvuk

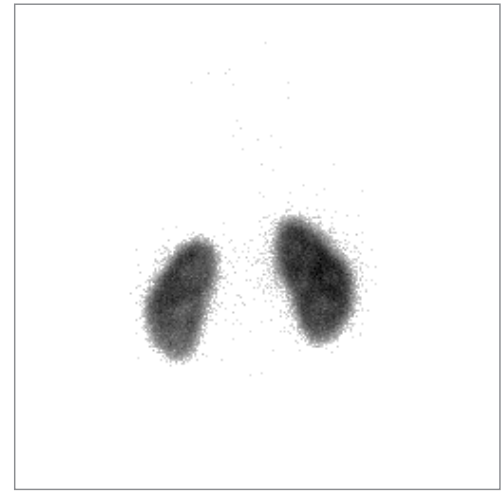

DMSA scintigram

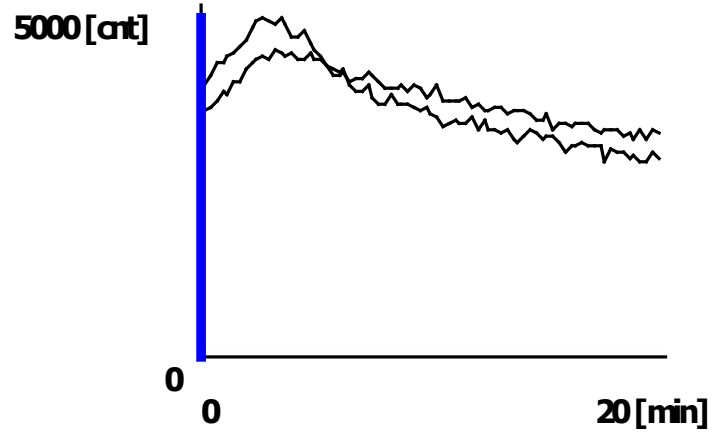

Radiorenogram 


\section{Hidronefroza II stepena:}
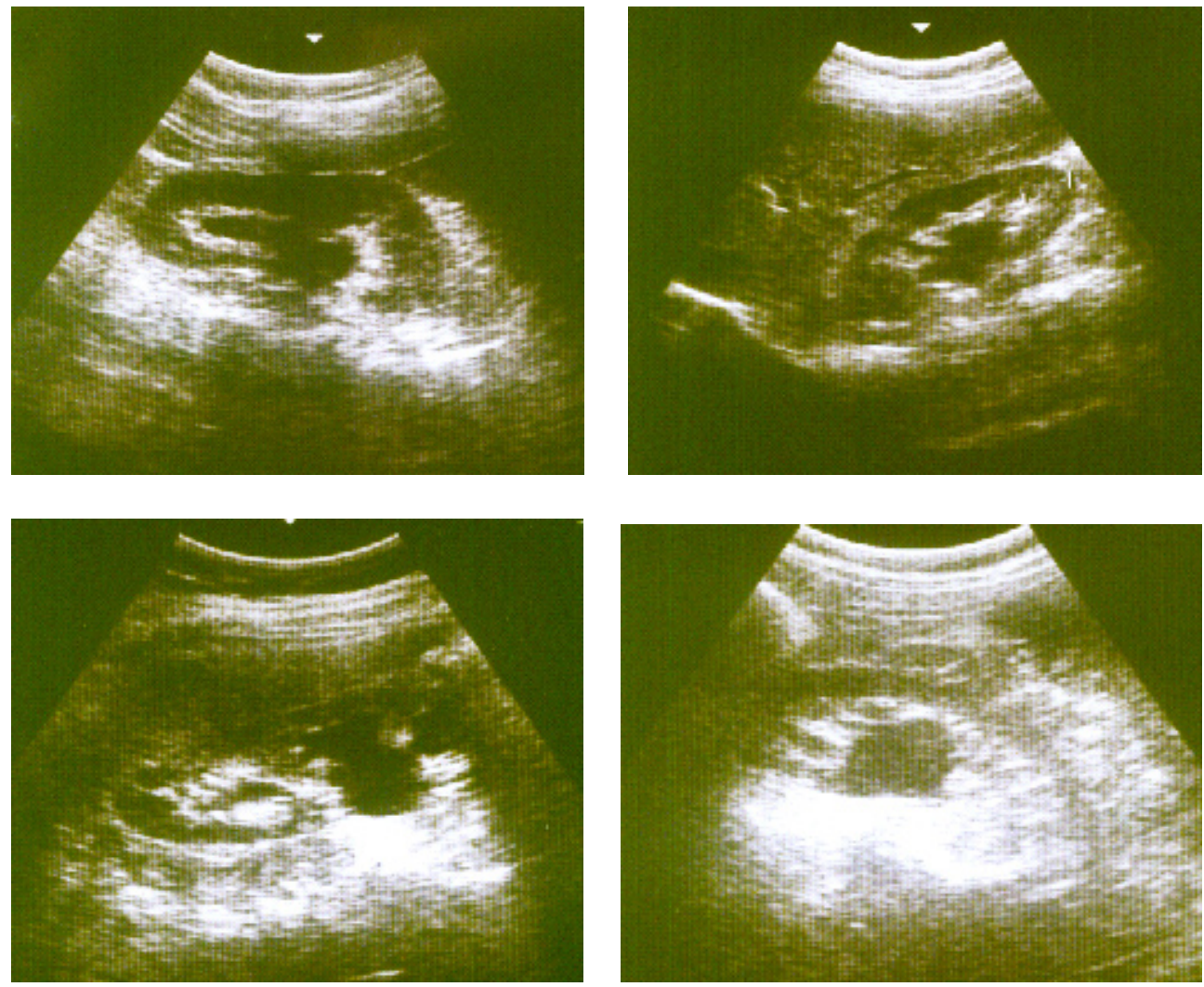

Ultrazvuk

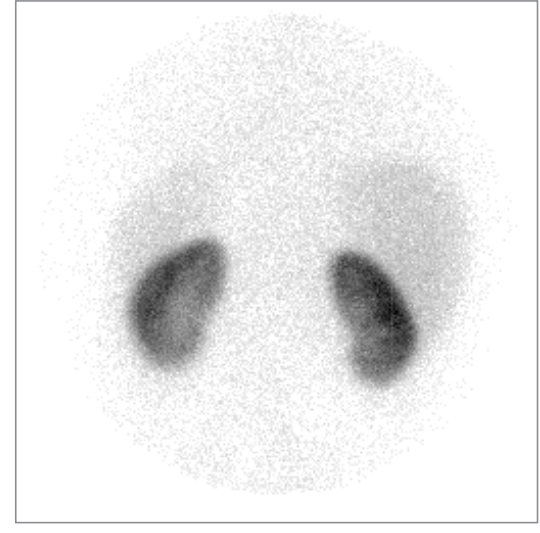

DMSA scintigram

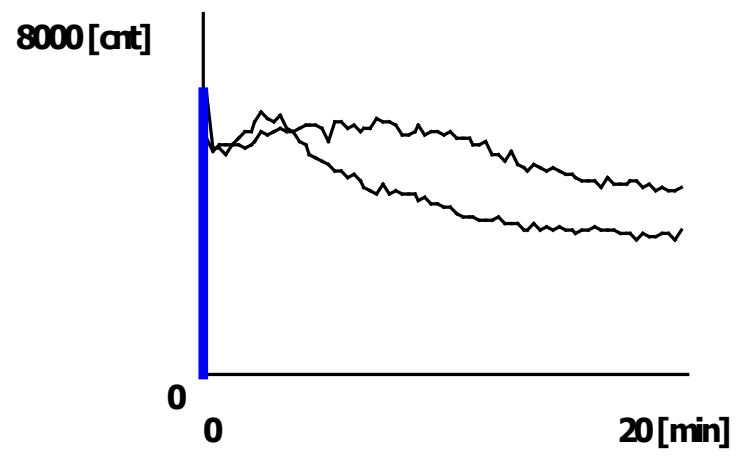

Radiorenogram 


\section{Hidronefroza III stepena:}
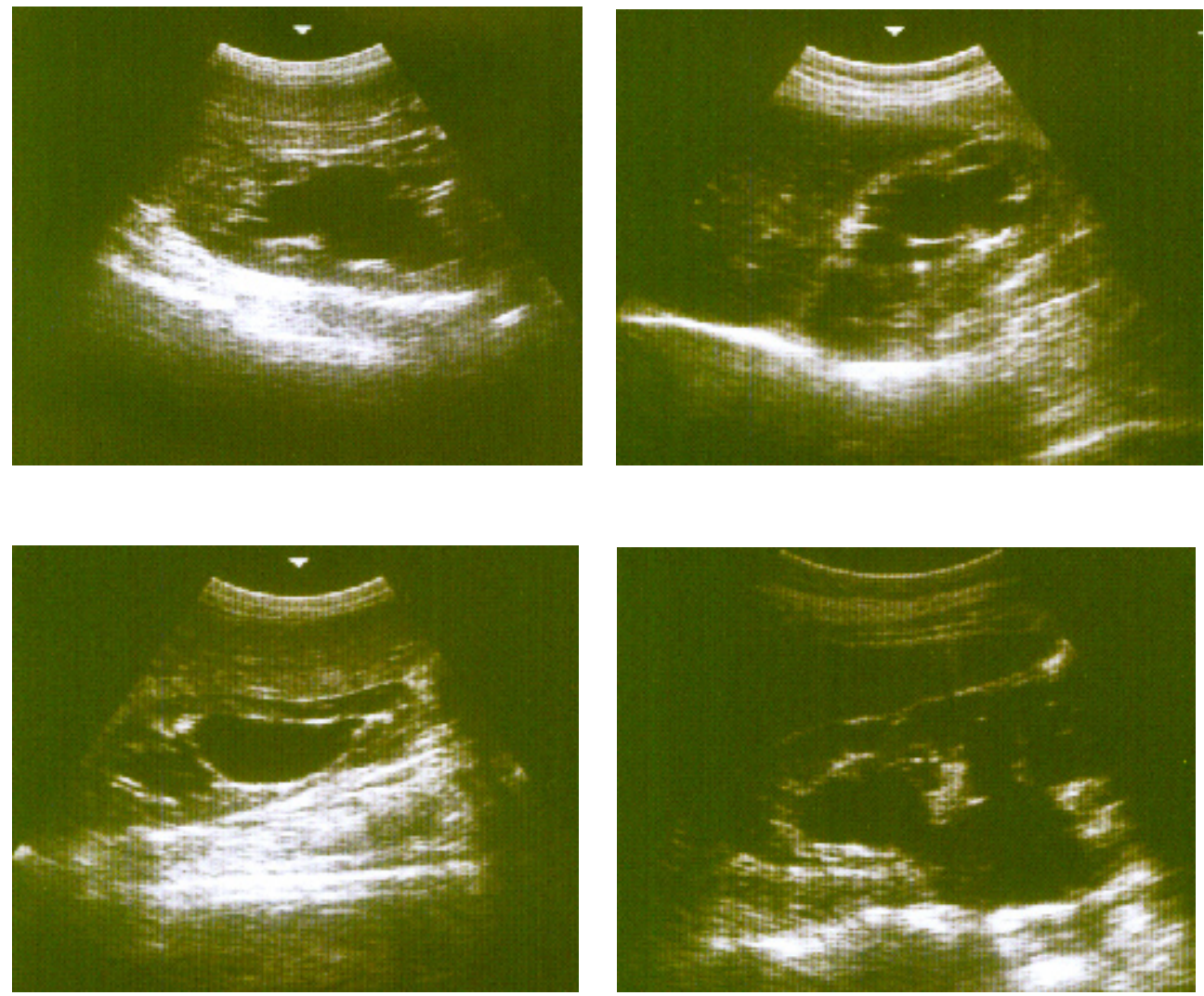

Ultrazvuk

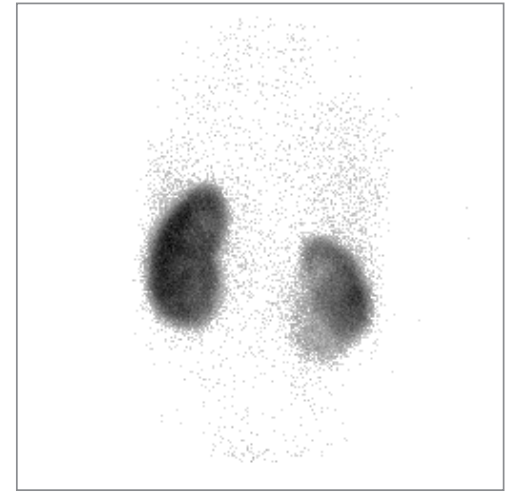

DMSA scintigram

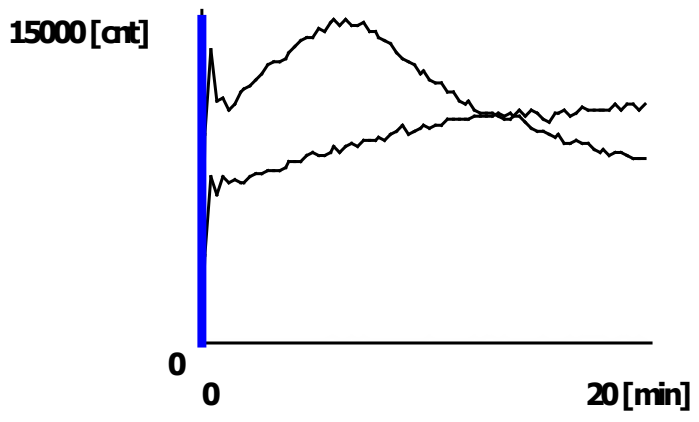

Radiorenogram 


\section{Hidronefroza IV stepena:}
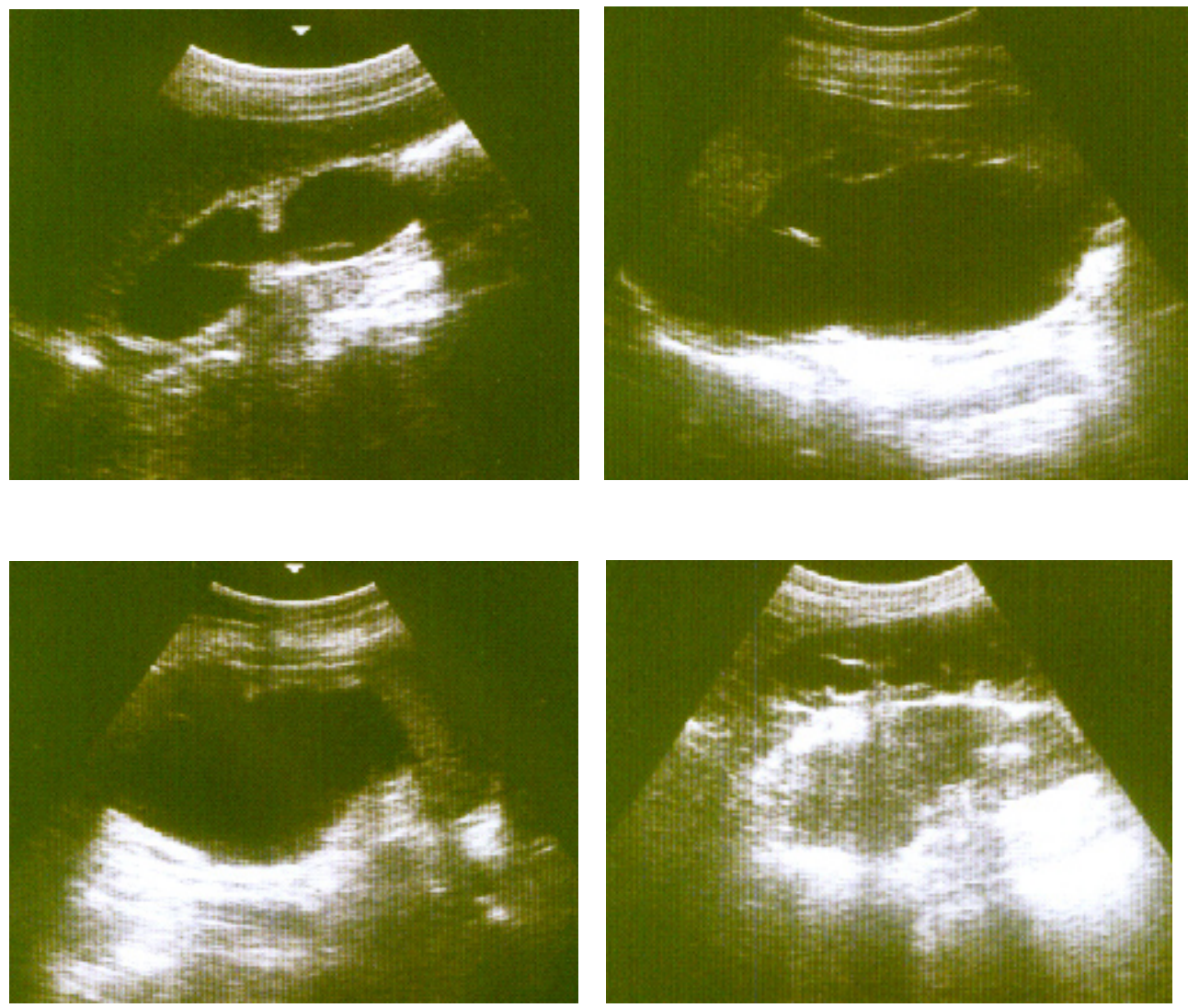

\section{Ultrazvuk}

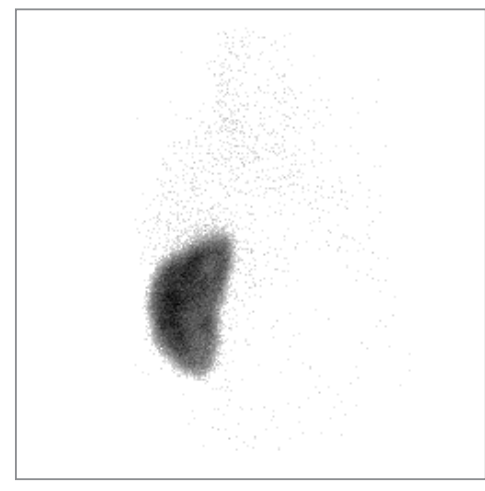

DMSA scintigram

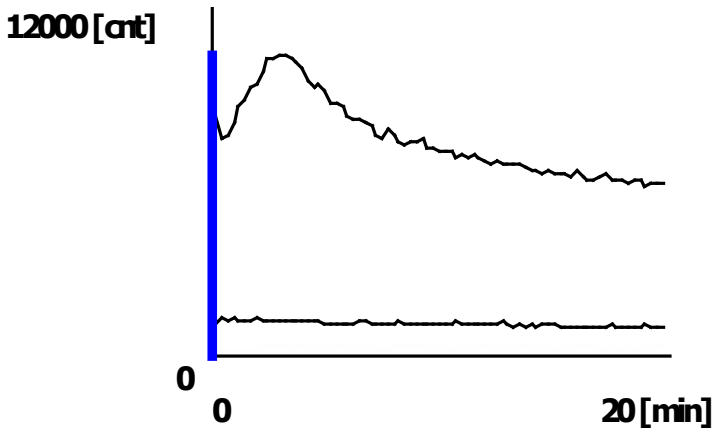

Radiorenogram 


\section{Merenje ultrazvučnih parametara:}

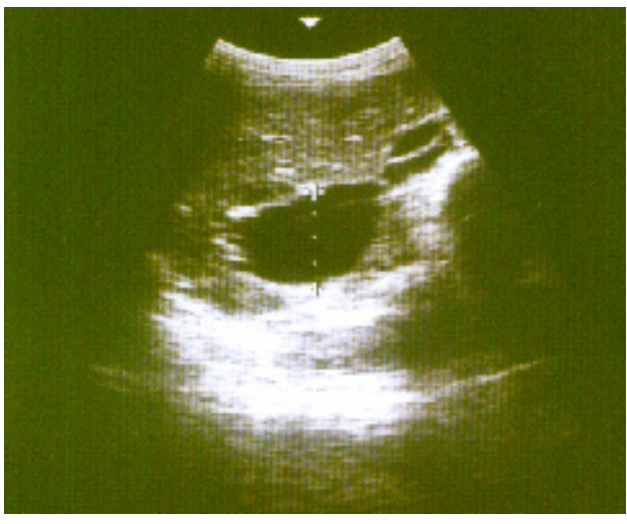

AP dijametar pijelona

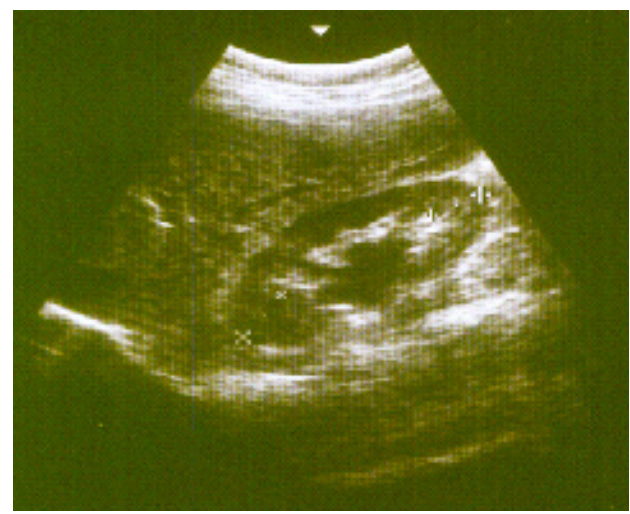

Bipolarna debljina parenhima

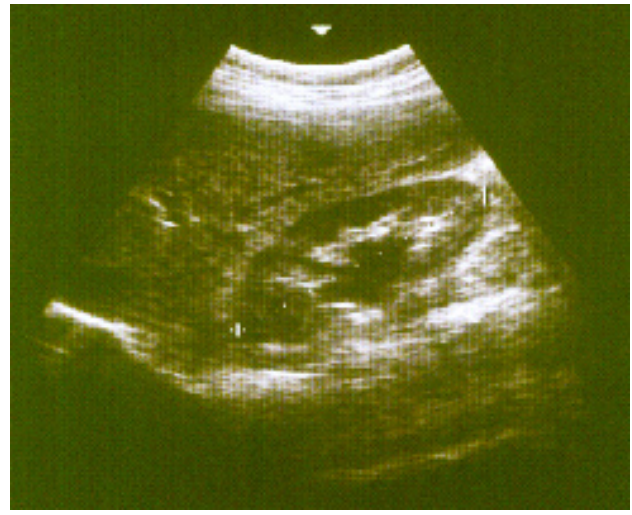

Dužina bubrega

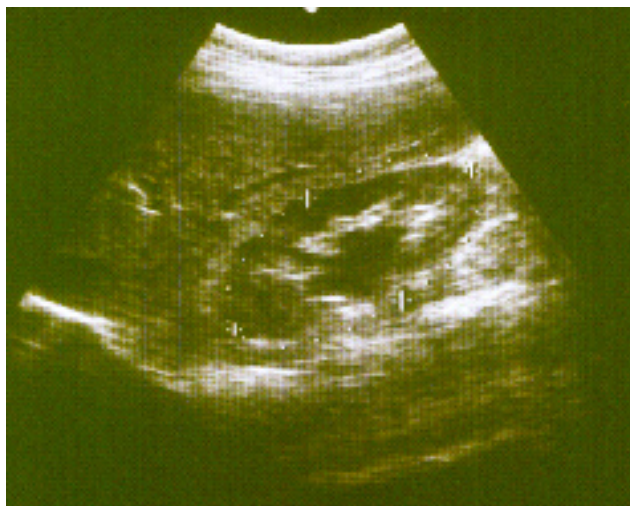

Površina bubrega

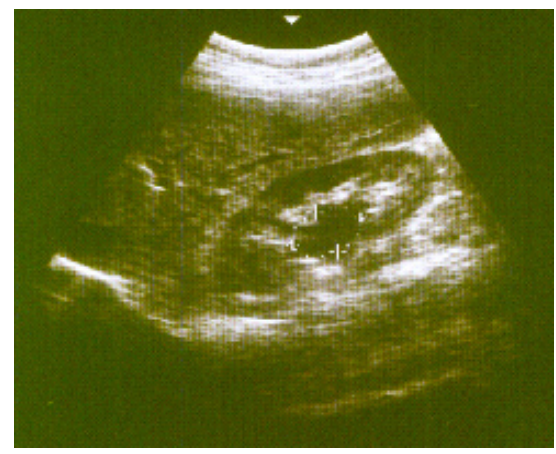

Površina pijelokaliksnog sistema 


\section{LITERATURA}

1. Lišanin Lj. Tehnika pregleda i ehotomografska anatomija bubrega i uretera. U Ultrazvuk u medicini. Markovć A. Ed. 381-386. Elit medica, Beograd, 1997.

2. Lišanin Lj. Opstruktivna stanja. U Ultrazvuk u medicini. Marković A. Ed. 391-395. Elit medica, Beograd, 1997.

3. Marković V. Hidronefroza. U Urologija. Marković V. Ed. 427-463. Novinsko-izdavačka ustanova Službeni list SRJ, Beograd, 1997.

4. Šljivić B. Sistematska i topografska anatomija (abdomen i karlica). Naučna knjiga, Beograd, 1976.

5. Draganić V., Petronić V., Lazić J., i ost. Bubreg i retroperitoneum. Naučna knjiga, Beograd, 1991.

6. Sedlak-Vadoc V. Primena nuklearne medicine u neforlogiji i urologiji. U Nuklearna medicina. Borota R., Stefanović Lj. Eds. 523-613. Unuiverzitet u Novom Sadu - Medicinski fakultet, Novi Sad, 1992.

7. Han R. Nuklearna nefro-urologija. U Osnovi nuklearne medicine. Milutinović P., Bošnjaković V., Kostić K. Eds. 173-187. Medicinski fakultet Univerziteta u Beogradu, Beograd, 1990.

8. Müller-Suur R. Radiopharmaceuticals: their intrarenal handling and localization. In Nuclear Medicine in clinical diagnosis and treatment. Murray I.P.C., Ell J.P. Eds. 211-228. Churchill Livingstone, Neww York, 1998.

9. Oei H.Y. Dynamic and static renal imaging. In Nuclear Medicine in clinical diagnosis and treatment. Murray I.P.C., Ell J.P. Eds. 229-244. Churchill Livingstone, New York, 1998.

10. Brown S.C.W. Nuclear Medicine in the clinical diagnosis and treatment of obstructive uropathy. In Nuclear Medicine in clinical diagnosis and treatment. Murray I.P.C., Ell J.P. Eds. 291-314. Churchill Livingstone, New York, 1998.

11. Tanagho E.A. Urinary obstruction and stasis. In Smith's General Urology. Tanagho E.A., McAninch J.W. Eds. 208-220. Lange Medical Books/McGraw-Hill, New York, 2000.

12. Kogan B.A. Disorders od the ureter and ureteropelvic junction. In Smith's General Urology. Tanagho E.A., McAninch J.W. Eds. 628-643. Lange Medical Books/McGraw-Hill, New York, 2000.

13. Jakšić E. Nuklearno-medicinska dijagnostika uroopstrukcije. U Interventna radiologija uroopstrukcije. Marković Ž. Ed. 55-69. Medicinski fakultet Univerziteta u Beogradu, Beograd, 1996.

14. O’Reilly P.H., Shields R.A., Testa H.J. Nuclear Medicine in urology and nephrology. Butterworths. London, 1986.

15. Weil F., Hihr E., Rohmer P. Zeltner F. Renal sonography. Springer, Berlin, 1981.

16. Smoljanić Ž.J. Procena težine opstrukcije gornjeg urotrakta u dece putem perkutane nefrostome. Doktorska disertacija, Medicinski fakultet, Beograd, 1995.

17. Goldner B., Panić I. Klinička rendgenologija urinarnog sistema. Medicinska knjiga Beograd-Zagreb, Beograd, 1985. 
18. Ležaić V. Opstrukcija mokraćnih puteva. U Bolesti bubrega. Đukanović Lj., Oštrić V. Eds. 299-314. Zavod za udžbenike i nastavna stredstva, Beograd, 1999.

19. Marković B. Balon kateterska rekanalizacija struktura proksimalnog dela uretera različite etiologije. Magistarska teza, Medicinski fakultet, Beograd, 1995.

20. Mašulović D. Metalni stentovi u lečenju struktura urinarnog trakta. Doktorska disertacija, Medicinski fakultet, Beograd, 2000.

21. Cost G.A., Merguerian P.A., Cheerasarn S.P., Shortliffe L. Sonographic renal parenchymal and pelvicaliceal areas: New quantitative parameters for renal sonographic followup. J Urol, 1996; 156: 725-729.

22. Bates J.A. The renal tract. In Abdominal Ultrrasound. Bates J.A. Ed. 139-176. Churchill Livingstone, Edinburgh, 1999.

23. Riccabona M. Assessment and management of newborn hydronephrosis. World J urol, 2004; 22(2): 73-8.

24. Peters C. Urinary tract obstruction in children. U Urol, 1995; 154: 1874-1884.

25. Noble V.E., Brown D.F. Renal ultrasoud. Emerg Med Clin North Am, 2004; 22(3): 641-59.

26. Marković V. Fiziologija bubrega. U Urologija. Marković V. Ed. 37-49. Novinsko-izdavačka ustanova Službeni list SRJ, Beograd, 1997.

27. Kozomara M., Šumarac Z., Bukuov N., Stefanović K. Lasix sonogram - nova metoda za procenu opstrukcije na nivou ureteropijeličnog segmenta. Urološki arhiv, 1986; 119-125.

28. Rossi P., Virgili S., Di stasi M., et al. Diuretic ultrasound. A non-invasive technique for the assessment of upper tract obstruction. Int BJU, 1990; 65: 566-569.

29. Mallek R., Bankier A.A., Etele-Hainz A., et al. Distinction between obstructive and nonobstructive hydronephrosis: value of diuresis duplex doppler sonography. AJR, 1996; 166: 113-117.

30. Konda R., Sakai K., Ota S., et al. Ultrasoud grade od hydronephrosis and severity od renal cortical damage on ${ }^{99 m}$ technetium dimercaptosuccinic acid renal scan in infants with unilateral hydronephrosis during followup and after pyeloplasty. J Urol, 2002; 167(5): 2159-63.

31. Gogus C., Karamursel T., Tokatli Z., et al. Long-term results of Anderson-Hynes pyeloplasty in 180 adults in the era of endourologic procedures. Urol Int, 2004; 73 (1): 11-4.

32. Apocalypse G.T., Oliveira E.A., Rabelo E.A., et al. Outcome of apparent ureteropelvic junction obstruction identified by investigation of fetal hydronephrosis. Int Urol Nephrol, 2003; 35 (4): 441-8.

33. Hafez A.T., McLorie G., Bagli D., Khoury A. Analysis of trends on serial ultrasound for high grade neonatal hydronephrosis. J Urol, 2002; 168 (4 Pt 1): 1518-21.

34. Csaicsich D., Greenbaum L.A., Aufrict C. Upper urinary tract: when is obstruction obstruction? Curr Opin Urol, 2004; 14 (4): 213-7.

35. Ylinen E., Ala-Houhala M., Wikstrom S. Outcome of patients with antenatally detected pelviureteric junction obstruction. Pediatr Nephrol, 2004; 19 (8): 880-7.

36. Kinn A.C. Ureteropelvic junction obstruction: long-term followup of adults with and without surgical treatment. J Urol, 2000; 164 (3 Pt 1): 652-6.

37. Gorshar D., Wakd M., Moskovitz B., et al. Quantitative SPECT of ${ }^{99 \mathrm{~m} T c-D M S A}$ uptake in kidneys of infants with unilateral junction obstruction: assessment of structural and functional abnormalities. J Nucl Med, 1999; 40 (7): 1111-5. 
38. Shokeir A.A. The diagnosis od upper urinary tract obstruction. BJU Int, 1999; 83: 893901.

39. Amling C.L., O’Hara S.M., Wiener J.S., et al. Renal ultrasound changes after pyeloplasty in children with ureteropelvic junction obstruction: long-term outcom in 47 renal units. J Urol, 1996; 156: 2020-2024.

40. Shokeir A.A., Provoost A.P., Nijman R.J.M. Recovarability of renal function after relif of chronic partial upper urinary tract obstruction. BJU Int, 1999; 83: 11-17.

41. Onen A., Jayanthi V.R., Koff S.A. Long-term followup of prenatally detected severe bilateral newborn hydronephrosis initially managed nonoperatively. J Urol, 2002; 168 : 1118-1120.

42. Chertin B., Rolle U., Farkas A., Puri P. Does delaying pyeloplasty affect renal function in children with a prenatal diagnosis of pelvi-ureteric junction obstruction? BJU Int, 2002; 90 (1): 72-5.

43. Ulman I., Venkata R., Jayanthi V., Koff S.A. The long-term followup of newborns with severe unilateral hydronephrosis initially treated nonoperatively. J Urol, 2000; 164: 1101-5.

44. Stauss J., Connolly L.P., Connolly S.A., et al. Dynamic renal scintigraphy in children with vesicoureteral reflux and suspected coexisting ureteropelvic junction obstruction. J Urol, 2003; 170 (5): 1966-70.

45. Imaji R., Dewan P.A. Calix to parenchyma ratio in pelvi-ureteric junction obstruction. BJU Int, 2002; 89(1): 73-7.

46. Rodriguez L.V., Lock J., Kennedy W.A., Shortliffe L.M. Evaluation of sonographic renal parenchymal area in the management of hydronephrosis. J Urol, 2001; 165 (6 Pt 2): 2293-5.

47. Thompson A., Gough D.C. The use od renal scintigraphy in assessing the potential for recovery in the obstructed renal tract in children. BJU Int, 2001; 87 (9): 853-6.

48. Sibai H., Salle J.L., Houle A.M., Lambert R. Hydronephrosis with diffuse or segmental cortical thining: impact on renal function. J Urol, 2001; 165 (6 Pt 2): 2293-5.

49. Ozcan Z., Anderson P.J., Gordon I. Assessment of regional kodney function may provide new clinical understanding and assist in treatment of children with prenatal hydronephrosis. J Urol, 2002; 168 (5): 2153-7.

50. Lam J.S., Cooper K.L., Greene T.D., Gupta M. Impact of hydronephrosis and renal function on treatment outcome: antegrade versus retrograde endopyelotomy.Urology, 2003;61(6):1107-11

51. Riccabona M. Potential of modern sonographic techniques in pediatric uroradiology. Eur J Radiol, 2002; 43 (2): 110-21.

52. Yamazaki Y., Yago R., Toma H. Sonographic characteristics of the urinary tract in healty neonates. J Urol, 2001; 166 (3): 1054-7.

53. Perez-Brayfield M.R., Kirsch A.J., Jones R.A., et al. A prospective study comparing ultrasound, nuclear scintigraphy and dynamic contrast enhanced magnetic resonance imaging in the evaluation of hydronephrosis. J Urol, 2003; 170 (4 Pt 1): 1330-4.

54. De Grazia E., Castagnetti M., Cimador M. Surgical or conservative treatment of congenital hydronephrosis. Ten years' expirience. Minerva Pediatr, 2001; 53 (4): 275-83. 
55. Mostbeck G.H., Zontsich T., Turetschek K. Ultrasound of the kidney: obstruction and medical diseases. Eur Radiol, 2001; 11 (10): 1878-89.

56. Yang Y., Ji S., Zhao G. Evaluation of renal function in children with moderate or severe hydronephrosis after opeation. Chin Med J, 2002; 115 (1): 123-5.

57. Farhat W., McLorie G., Bagli D., Khoury A. Greater reliability of neonatal ultrasonography in deffining renal hypoplasia with antenatal hydronephrosis and vesicoureteral reflux. Can J Urol, 2002; 9 (1): 1459-63.

58. Aziz M.A., Hossain A.Z., Banu T., et al. In hydronephrosis less than $10 \%$ kidney function is not an indication for nephrectomy in children. Eur J Pediatr Surg, 2002; 12 (5): 304-7.

59. Ramonas H., Zelvys A. Treatment of patients with urinary tract obstruction and significant renal impairment. Medicina (Kaunas), 2002; 38 Suppl 1: 30-5.

60. Diaz E.A., Martinez B.M., Duenas G., et al. Comparative study of diferential renal function by DMSA and MAG-3 in congenital unilateral uropathies. Cir Pediatr, 2002; 15 (3): 118-21.

61. Fritz G.A., Riccabona M., Bohdal G., et al. Accuracy of renal volume assessment in children by three-dimensional sonography. Rofo Fortschr Geb Rontgenstr Neuen Bildgeb Verfahr, 2003; 175 (4): 540-6.

62. Rufini V., Garganese C.M., Perotti G., et al. The role of nuclear medicine in infantile hydronephrosis. Rays, 2002; 27 (2): 141-8.

63. Eisenhardt A., Arntzen D., Conrad S., et al. Occurrence, diagnostics and therapeutic management of hydronephrosis in pediatric patients in Germany. Urologe A, 2003;42(4):538-46.

64. Moon D.M., Park Y.S., Jun N.L., et al. Value of supranormal function and renogram patterns on ${ }^{99 m} \mathrm{Tc}-$ mercaptoacetyltriglycine scintigraphy in relation to the extent of hydronephrosis for predicting ureteropelvic junction obstruction in the newborn. J Nucl Med, 2003; 44 (5): 725-31.

65. Thorup J., Jokela R., Cortes D., et al. The results of 15 years of consistent strategy in treating antenatally suspected pelvi-ureteric junction obstruction. BJU Int, 2003; 91 (9): 850-2.

66. Rigas A., Karamanolakis D., Bogdanos I., et al. Pelvi-ureteric junction obstruction by crossing renal vessels: clinical and imaging features. BJU Int, 2003; 92 (1): 101-3.

67. Koff S.A. „The beneficial and protective effects od hydronephrosis”. APMIS Suppl, 2003; (109): 7-12.

68. Paick S.H., Oh S.J., Song Y.S., Kim H.H. The natural history of hydronephrosis after radical hysterectomy with no intraoperatively recognisable injury to the ureter: a prospective study. BJU Int, 2003; 92 (7): 748-50.

69. Eskild-Jensen A., Munch Jorgensen T., Olsen L.H., et al. Renal function may not be restored when using decreasing differential function as the criterion for surgery in unilateral hydronephrosis. BJU Int, 2003; 92 (7): 779-82.

70. Cheng A.M., Phan V., Geary D.F., Rosenblum N.D. Outcome od isolated antenatal hydronephrosis. Arch Pediatr Adolesc Med, 2004; 158 (1): 38-40.

71. Tan B.J., Smith A.D. Ureteropelvic junction obstruction repair: when, how, what? Curr Opin Urol, 2004; 14 (2): 55-9. 


\section{TSH-OM OD SUMNJE DO KONAČNE DIJAGNOZE - PRIKAZ SLUČAJA}

\section{Uvod}

TSH-omi- sekretujući makroadenomi su retki, ali kada se jave veoma su veliki i lokalno invazivni. Bolesnici imaju tireoidnu strumu i hipertireoidizam, usled hipersekrecije TSH. Dijagnoza se zasniva na dokazivanju povišene sekrecije slobodnog T4 u serumu, neadekvatno normalne ili povišene sekrecije TSH I NMR dokazom hipofiznog adenoma. Čine $2 \%$ od svih tumora hipofize.

Lečenje: Početni terapijski cilj je odstranjivanje ili smanjenje tumorske mase operativnim putem, bilo transfenoidalnim bilo subfrontalnim pristupom. Totalna resekcija se uglavnom ne postiže, jer je najveći broj ovih adenoma veliki i lokalno invazivan. Kod oko 2/3 ovih pacijenata nakon operacije normalizuje se koncentracija tireoidnih hormona u krvi. Antitireoidni lekovi se koriste za redukovanje koncentracije tireoidnih hormona.

Lečenje analogom somatostatina može da se normalizuje hipersekrecija TSH i smanji veličina tumora kod $50 \%$ bolesnika i poboljša vidno polje kod $75 \%$ bolesnika.

Kod najvećeg broja bolesnika uspostavlja se eutireoidizam. Kod nekih bolesnika oktreotid značajno suprimuje TSH uzrokujući hipotireoidizam, koji tada zahteva supstituciju levotiroksinom. Lanreotid

(30 mg I. M. svakih 14 dana), dugodelujući analog somatostatina, efikasno suprimuje TSH i tireoidne hormone bolesnika.

Prikaz slučaja: Pacijent K.P. (20 godina) dolazi u ambulantu štitaste žlezde Specijalne bolnice „Čigota” zbog lupanja srca pri naporu, naglog rasta (TV: $201 \mathrm{~cm}$, TT: $79,5 \mathrm{~kg}$ ), pojačanog znojenja i nesanice. Tegobe perzistiraju unazad dve godine. Sam je pročitao na internetu o simptomima hipertireoze I došao na pregled.

Klinički jasno hipermetaboličan, bez znakova endokrine oftalmopatije.

Hormonski status štitaste žlezde: FT4: 154,8, (10,2-24,5) TT3: 9,2 (1,1-3,1), TSH: 26,91 (0,42-4,2), Anti-TPO at: 10, Kalcitonin: 2,47. 